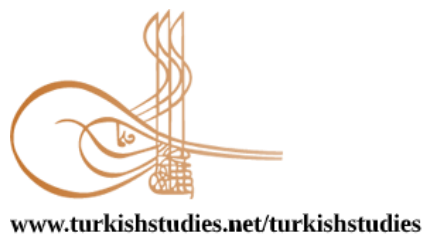

Turkish Studies

www.turkishstudies.net/turkishstudies

eISSN: 1308-2140

BALKAN
UNIVERSTTY

Sponsored by IBU

Research Article / Araştırma Makalesi

\title{
Covid-19 Sürecinde YouTube'daki Doktor Videolarının WHO ve Türkiye Cumhuriyeti Sağlık Bakanlığı Söylemleri ile Karşılaştırılması
}

\author{
Comparison of Doctor videos on YouTube with Who and Turkish Ministry of Health Discourses \\ During Covid-19
}

\author{
İsmail Baydili*
}

\begin{abstract}
Covid-19, which spread rapidly and was declared a pandemic around the world, had greatly impacted the success of 2020 and people's lives. Most countries had to take measures to restrict the social life of their citizens in order to combat Covid-19. The measures taken have caused fear and an associated anxiety of Covid-19 in humans. People under the influence of fear and anxiety searched for information in various media in order to obtain information about Covid-19. YouTube is one of the most frequent websites visited by information seekers. YouTube is today's money-making next-generation media platform. Content producers often make their videos up-to-date and be able to attract everyone's attention, as viewing rate is one of the main determinants of the amount of money they earn. The fact that Covid-19 is one of the most popular topics in recent time has prompted YouTube content producers to focus on it. However, most of the videos contain hearsay and inaccurate information about the virus. The videos of the YouTube doctors' opinions largely do not correspond with the statements of WHO and the Ministry of health of the Republic of Turkey. This research is aimed at determining how much YouTube, which has the potential to meet the public's need for information in such an important situation, delivers healthy information by examining whether YouTube platform doctors' opinions coincide with the WHO and the Ministry of Health's statements on Covid-19.
\end{abstract}

Structured Abstract: One of the biggest problems with Covid-19 is the circulation of too much false information. The excess of erroneous information is a major obstacle for individuals who want to get accurate information about the virus. As part of the research, videos of YouTube doctors transmitting information about Covid-19 were compared with statements of institutions and organizations affiliated with the WHO and the Ministry of Health, and it was observed that a lot of conflicting information was shared in the videos. It is very important to determine the situation that causes confusion among those who want to get information about a process that deeply affects community life and humanity, and to find solutions in order not to encounter such a problem again.

The study compared the Covid-19 discourses on official websites of institutions and organizations related to WHO and the Ministry of health of the Republic of Turkey, and the discourses of doctors on YouTube videos. Thus, the compatibility or contradiction of the videos with official discourse were determined. The

\footnotetext{
* Öğr. Gör. Dr., Fırat Üniversitesi, Teknik Bilimler MYO, Radyo ve Televizyon Programcılı̆̆ı Programı. Lecturer Dr., Firat University, Vocaitional School.

ORCID 0000-0001-8563-8342

ibaydili@firat.edu.tr

Cite as/ Atıf: Baydili, İ. (2020). Covid-19 sürecinde YouTube'daki doktor videolarının WHO ve Türkiye Cumhuriyeti Sağlık Bakanlığı söylemleri ile karşılaştırılması. Turkish Studies, 15(4), 153-178. https://dx.doi.org/10.7827/TurkishStudies.44188

Received/Geliş: 12 June/Haziran 2020

Accepted/Kabul: 10 August/Ağustos 2020

Copyright $(\mathrm{C}$ MDE, Turkey

Checked by plagiarism software Published/Yayın: 30 August/Ağustos 2020 CC BY-NC 4.0
} 
information transfer levels of the videos were also examined and it was investigated whether or not a satisfactory information transfer about Covid-19 was made.

Very little information about Covid-19 was found to have been shared in the videos examined. It is understood that those who want to get information about Covid-19 may not have obtained full information about Covid-19 even after watching several videos., It is clear that In a time of anxiety and fear, rather than the discourse that will create controversy, videos that will share informative knowledge to the society, that will spread the air of anxiety and fear, and information that guides correctly, will contribute more to the fight against the virus. The videos were unable to transmit comprehensive information, nor did they convey knowledge on how to access comprehensive information. It was only the 5th and 10th videos that directed those who want to reach more comprehensive information to the addresses affiliated with WHO and the Ministry of Health.

Today, YouTube's most used purpose is for entertainment, but its use in accessing health information is also important and is predicted to increase rapidly (Gabarron, Fernandez-Luque, Armayones, and Lau, 2013:2). In our age, every stage of information takes place via the internet. Thus, even education systems are integrated into internet-based systems and the internet is becoming more and more powerful as an indispensable element of every field (Henkoğlu, Keser, \& Mahiroğlu, 2017: 146). Easy access to information on the Internet strengthens the internet preference in the method of accessing information, leading to a number of problems. The ease of producing content on YouTube, a free platform, and the presence of irregular information in the generated content can be an obstacle to getting the right information. Videos that convey information about health can be "homemade" videos based on personal experiences, as well as videos that convey the opinions of experts on a variety of subjects. Those who watch the videos for information are unaware of the producer of the videos, when they were updated, and how much of the information in its content is correct (Pant vd., 2012: 281-282). These situations raise the issue of reliability of information on YouTube. The reliability problem also applies to videos related to the Covid-19 virus.

YouTube, a video-sharing app created for entertainment purposes, also hosts many health-related videos. Considering its high popularity and ease of access, the effects of videos on people will be more easily understood. The fact that such an effective platform contains low-quality health information causes people accessing the information to be misinformed. Videos about an epidemic such as Covid-19 that is spreading fast and causing a major problem in the world, and we are trying to prevent its spread with serious sanctions such as lockdowns, school holidays, travel bans, , require more regular and clear information. The fact that a false knowledge learned from this platform can negatively affect many people's lives and even lead to unwanted deaths should be considered.

YouTube is a free platform, although it has certain legal and moral limits. But freedom should not mean unsupervised or uncontrolled. In particular, it can be expected that there are certain limitations in the sharing of health-related information and specific qualifications in order to produce such content. The intention here is not censorship from supervision and control. It is unacceptable to apply a repressive method like censorship in a libertarian environment like YouTube. Various solutions should be found in order to produce videos that affect large audiences with certain production qualities, especially in the field of health. The idea that "let people choose what they want, follow what they want, believe what they want" can be considered a luxury in health care, especially in pandemics such as Covid-19 that threaten very large audiences. In the fight against the pandemics, YouTube videos should also be restricted if we can be restricted from going out on the streets, going on holiday, sitting in cafes, restaurants and similar places, and being in crowded environments for both the individual and the public interest. The supervision and security issues that are often mentioned in social media studies, especially on terrorism, should also apply to social media content on health.

Keywords: Video Analysis, Epidemic, Discourse Review, New Media, Covid-19.

Öz: 2020 yılının başalarında dünya çapında hızlı bir şekilde yayılan ve pandemi ilan edilmesine neden olan Covid-19 insanların yaşamlarına büyük oranda etki etmiştir. Çoğu devlet Covid-19 ile mücadele edebilmek için vatandaşlarının sosyal hayatını kısıtlayıcı önemler almak zorunda kalmıştır. Alınan önlemler insanlarda Covid-19'a karşı bir korku ve bu korkuya bağlı bir kaygıya neden olmuştur. Korku ve kaygının etkisinde olan insanlar Covid-19 ile ilgili bilgi elde edebilmek için çeşitli mecralarda bilgi arayışı gerçekleştirmiştir. Bilgi arayanların sıklıkla ziyaret ettiği internet sayfalarından birisi de YouTube'tur. YouTube günümüzün para kazandıran yeni nesil medya platformudur. Videoların izlenme oranları, içerik üreticilerinin kazandıkları

Turkish Studies, 15(4) 
paranın ana belirleyicilerinden birisi olduğu için içerik üreticileri genellikle videolarını güncel ve herkesin dikkatini çekecek konulardan oluşturmaktadır. Covid-19'un son dönemin en popüler konularından biri olması, YouTube içerik üreticilerinin de bu konuya eğilmelerini sağlamıştır. Fakat çekilen videoların büyük bir bölümü virüs ile ilgili kulaktan dolma ve hatalı bilgiler barındırmaktadır. YouTube'daki doktor görüşlerinin aktarıldığı videolar ise WHO ve Türkiye Cumhuriyeti Sağlık Bakanlığı'nın açıklamaları ile büyük bir oranda örtüşmemektedir. Bu araştırma, YouTube platformundaki doktor görüşlerinin WHO ve Sağlık Bakanlı̆̆ı'nın Covid-19 ile ilgili açıklamalarıyla örtüşüp örtüşmediğini inceleyerek, böylesine önemli bir durumda toplumun bilgi alma ihtiyacını karşılama potansiyelinde olan YouTube'un sağlıklı bilgiye ne kadar ulaştırdığını ortaya koymayı amaçlamıştır.

Anahtar Kelimeler: Video analiz, Salgın, Söylem incelemesi, Yeni Medya, Covid-19.

\section{Giriş}

İnsanlar bilmedikleri konularda meraklarını gidermek için çeşitli yöntemler kullanırlar. Bu yöntemlerden birisi de internet araştırmalarıdır. İnternet aracılığı ile insanlar aradıkları verilere çok hızlı bir şekilde ulaşabilmektedir. Teknolojik gelişmeler sayesinde internet birçok insan için bilgiye kolay, ucuz ve hızlı ulaşımı sağlamaktadır. Arama motorları, Web tarayıcıları, elektronik kütüphaneler, dergi ve gazete veri tabanları gibi öğeler ihtiyaç duyulan bilgiye ulaşmada avantaj sağlayan yeni yöntemlerdir (Kurulgan \& Argan 2007: 291). Bu avantajları ile internet, bilgiye ulaşmada kullanılan geleneksel yöntemlerin önüne geçmeyi başarmıştır. Özellikle 1998 yılında Google'ın kurulması ile başlayan etkileşimsel hareketliliğin ardından kurulan bloggerlarla insanlar içerik paylaşımına başlamıştır (Tosyalı \& Sütçü, 2016: 9).

Yeni medya da internet teknolojisinden beslenmektedir. Yani yeni iletişim teknolojileri geleneksel medya anlayışının değişime uğramasını sağlayarak yeni medyanın oluşumunu sağlamıştır (Kırık, 2017:230). Yeni medya ile geleneksel medya düzeni kökünden değişmiştir. Yeni medya ile merkezsizleşmiş, açık, ağ tabanlı, sınırsız ve etkileşimli bir dönem başlamıştır (Aydoğan \& Kırık, 2012:59). 2000'li y1llardan beri en popüler kavramlardan biri olan yeni medyada ifade edilmesi gereken bir nokta "yeni" sıfatının taşıdığı anlamdır. "Yeni" ifadesi kalıcı bir ifade değildir. Her teknoloji bir öncekini eskitmekte ve yeni olarak ifade edilebilmektedir, fakat yeni medya denildiğinde anlatılmak istenilen tek şey teknolojik yenilik değildir. Geleneksel medya ile yeni medyanın farklılıkları ve geleneksel medyada olmayan kullanım biçimleri ile bu kullanım biçimlerinden ortaya çıkan toplum-medya ilişkisi de anlatılmaktadır (Altunay, 2015:411).

Yeni medyayı geleneksel medyadan farklılaştıran özellikler; sayısallık, taşınılabilirlik, eşzamansızlık, etkileşimlilik, kitlesizleştirme, kişiselleştirebilme ve yöndeşmedir (Altunay, 2013; Altunay, 2015:412). Bu farklardan en önemlisi etkileşimliliktir. Geleneksel medyada pasif durumda olan bireyler yeni medya ile aktif yani etken bir duruma gelmiştir. Böylece iletişim çift taraflı bir boyut kazanarak alıcı-kaynak yer değişmesi mümkün hale gelmiştir (Aydoğan \& Kırık, 2012:60). Geleneksel medyanın "aynı anda"lık mecburiyetinin ortadan kalkışı da yeni medyanın getirdiği önemli yeniliklerden birisidir. Fakat yeni medyanın popülerleşmesini sağlayan en güçlü yönü geleneksel medyaya göre daha ucuz oluşu ve geleneksel medyanın profesyonel yapısına ihtiyaç duymamasıdır (Yurdgül \& Zinderen, 2012:84).

Bu bakış açısı ile değerlendirdiğimizde geleneksel medya (Bailey, vd, 2008: 18; Aydoğan \& Kırık, 2012: 67):

- Homojen ve geniş ölçekli kitleye hitap eden,

- Profesyonellerin kontrolünde,

- Egemen söylem taşıyıcısıdır.

Yeni medya (Bailey vd, 2008: 18; Aydoğan \& Kırık, 2012: 67):

- Küçük, spesifik gruplara yönelen, 
- Bağımsız,

- Daha demokratik, daha ulaşılabilir ve daha katılımcı,

- Hiyerarşik yapısı olmayan,

- Hegemonyacı söylem barındırmayan bir yapıdadır.

Yeni medyanın gelişmesi ile hayatımıza giren bir diğer yenilik de sosyal medyadır. Sosyal medya ile insanlar çeşitli araçlarla (bilgisayar, tablet, telefon vb.) fiziksel olarak çok uzakta yapılan paylaşımlardan haberdar olabilme, beğenebilme ya da yorum yapabilme olanağına kavuşmuştur. Sosyal medya ağlarının her geçen gün daha da güçlenmesi web sitelerinin yerini almaya başlamasına neden olmuştur. Böylece web sitelerindeki çeşitli bilgiler sosyal medya kullanıcıları tarafından daha hızlı bir şekilde ulaşılabilir olmuştur (Kırık, 2017:241). Bilgiye erişimin kolaylaşması ve sosyal medyanın bireysellik özelliği ile kullanıcı destekli içerik üretme imkânının bilgiyle birleşmesi, bilginin yeniden yorumlanmasını da olanaklı hale getirmiştir. Sosyal ağlar sayesinde insanlar aradıkları ya da ilgilendikleri içeriklere hızlı bir şekilde ulaşmaya başlamıştır. Küçük gruplar arasında geçen paylaşımlar giderek daha artan bir hal almış ve dijital dünyada birer değere dönüşmüşlerdir (Öztürk, 2015: 289).

Mavnacıŏlu (2009: 64), sosyal medyanın özelliklerini şu şekilde sıralamaktadır (Öztürk, 2015: 292):

- Zaman ve mekânın öneminin ortadan kalktığı, paylaşım ve tartışmaların merkez olduğu internet zinciridir.

- Bireysel üretilmiş içerikler çok kolay bir şekilde geniş kitlelere yayılmaktadır.

- Bireyler başkalarının içerik ve yorumlarını takip edebilmektedir.

- Bireylerin hem takip edildiği hem de takip ettiği bir ortamdır.

- Kuralların fazla dikkate alınmadığı, temel mantığın samimi sohbet olduğu bir yapıdadır.

- İçerikleri daha çok informeldir.

2004 yılında gelen Facebook ile sanal kimlikler gerçek kimliklerin önüne geçerken, 2005 yılında hayatımıza giren YouTube tamamen kullanıcıların oluşturduğu içerikleri hayatımıza sokmuştur (Tosyalı \& Sütçü, 2016: 9). "Dijital in 2019 Global Overview" raporu YouTube'nin etkin bir ortam olduğunu gözler önüne sermektedir. Rapora göre en çok ziyaret edilen "Google" sitesinin ardından ikinci sırada YouTube gelmektedir (https://datareportal.com). YouTube'un bu kadar etkin olmasının temel nedenlerinden ilki kullanıcıların sadece tüketici olmayıp aynı zamanda üretici imkânına da sahip olmasıdır. 88 Ülkede 76 farklı dilde kullanılan YouTube internet kullanıcılarının \%95'ine ulaşmaktadır (Aydoğdu, 2018:142). Ying'ın ifadesiyle (2007:17) "YouTube'un amacı kullanıcılarına kolay ve eğlenceli bir deneyim yaşatmaktır." "Aynı zamanda dijital bir kütüphane olma özelliği taşıyan YouTube platformu; müzikten eğitime, sağliktan eğlenceye, oyundan tv dizilerine kadar çok kapsamlı içeriğe sahiptir" (Burgess \& Green, 2009: 94; Aydoğdu, 2018: 144). Geleneksel medya ile yeni nesil medya arasındaki geçişin simgelerinden olan YouTube ile "we" olan internet artık "you" şeklini almıştır (Spencer, 2014:1; Aydoğdu, 2018:146). Basit bir arayüz ile oldukça kullanışlı bir platform haline gelen site geniş bant teknolojisi ile daha da popüler bir hal almıştır. YouTube içerikleri herkese açı, listelenmeyen ve özel olarak yayınlanabilmektedir. Lange (2007) kullanıcıları açısından YouTube'u ele aldığında "eski kullanıcılar (former participants), siradan kullanıc1lar (casual users), aktif katılımcilar (active participants), youtuberlar (YouTubers or Tubers) ve Youtube ünlüleri (YouTube celebrities) olmak üzere beş kategoriye ayırmıştır (Işık, 2018: 386). Ayrımda dikkati çeken kategori Youtuber kategorisidir. YouTube ile hayatımıza giren bu kavramını, hazırladıkları içerikleri kendi YouTube kanallarından paylaşarak geniş kitlelere ulaşan, izleyicileri ile kurdukları bağ sayesinde birçok faktörden beslenen ( Tolson, 2010; Yaraş, 2017, 57; Iş1k, 2018:386) ve bu yöntemle para kazandıran bir meslektir (Aydoğdu, 2018:141). Özetle YouTube birçok bilginin ve deneyimin aktarıldığı yeni bir sosyal mecra olarak yaşamımızda önemli bir yer 
edinmiştir. Günümüzde YouTube yeni nesil bilgiye ulaşma yöntemlerin en pratiklerinden birisidir. Çünkü YouTube okumaya bile gerek olmadan birilerinin çektiği videolar sayesinde bilgiye daha kolay ulaşılmasını sağlamaktadır.

Yapılan çalışmalar sağlık sorunları hakkında bilgi arayanların da internetten faydalandığını göstermektedir. Örneğin 2005 yılında internet erişimi olan 15 milyon Kanadalı'nın \%58'inin, sağlık bilgilerine ulaşmada interneti kullandığı anlaşılırken, ABD'de 2005 yılında yetişkinlerin \%53'ünün sağlık bilgisi almak için internete eriştiğini, aynı sayının 2006'da \%61, 2007'de ise \%71'e yükseldiğini göstermiştir (Paré vd., 2009: 1). Bununla beraber internetteki düzensiz bilgiler yanlıs bilgi potansiyelini de taşımaktadır. İnternetteki bilgilerin kimin tarafından yüklendiği, ne sıklıkla güncellendiği ve ne kadar doğru olduğu ile ilgili bilgilerden kullanıcılar genellikle habersizdir (Pant vd., 2012: 281). YouTube'ta aktarılan bilgiler ile ilgili yapılmış çok sayıda çalışma mevcuttur. Özellikle sağlık konusunda aktarılan bilgilerin incelendiği çalışmaların (aşılar, çeşitli kanser türleri, H1N1, İnfluenza, böbrek taşı, yanık tedavileri, bağırsak hastalıkları, kalp problemleri, epilepsi vd.) (Hansen vd., 2016: 35) varlığı ve sayıca çokluğu YouTube'un etkin bir bilgi aktarım aracı olduğunu göstermektedir. YouTube her ay 1.9 milyar kişinin ziyaret ettiği, günde 5 milyardan fazla videonun izlenildiği 91 ülkede 80 dilde desteğin olduğu bir platformdur. Gençlerin \%96's1 YouTube'u kullanmaktadır ve 18 yaş civarı gençlerin büyük bir bölümü YouTube'u bilgiye ulaşma yeri olarak kullanmaktadır (www.brandingturkiye.com).

\section{İnternet Ortamında Sağlık Bilgisi Arama}

İçinde bulunduğumuz bilgi çağının en önemli iletişim aracı bilgisayar ve ardından geliştirilen internet teknolojisidir. Bu yeni teknolojiler günümüz insanının odak noktası haline gelmiștir. Yaşam alanlarımızın birçok noktasında bilgisayar ve internet kullanılmaktadır. İnternet sayesinde insanlar üretilmiş bilgiyi saklama, paylaşma ve istenilen anda ulaşma imkânına sahiptir (Çalık \& Çınar 2009: 84). İnternetin en büyük avantajı evrenselliğidir. Evrenselliğinin yanında sunduğu aktarım ve erişim kolaylığı, ekonomik olarak maliyetinin düşük olması şeklindeki avantajları ile geleceğin tek medyası olarak görülmektedir (Maigret, 2012: 329). Her geçen gün hızla artan internet kullanımı, 2019 yılı verilerine göre dünya nüfusunun $\% 58.7$ 'sine ulaşmıştır. Yani günümüzde dünya nüfusunun yarısından fazlasının artık internet erişimi vardır. İnternet kullanımı dünya üzerinde eşit bir şekilde dağılmamış, bazı bölgelerde erişim oranı oldukça yüksekken bazı bölgelerde ise düşük kalmıştır. Örneğin Afrika'da internet erişimi \%39,3 oranındayken, Kuzey Amerika'da \%94,6 oranında internet erişimi mevcuttur. Asya'da \%53,6, Avrupa'da \%87,2 oranında olan internet erişimi Türkiye'de ise \%83,3'tür (www.internetworldstats.com 2020). Türkiye'de internet kullanımı ile ilgili Türkiye İstatistik Kurumu'nun (TUIK) yaptığı çalışmalar (2016) incelendiğinde, her on haneden sekizinin internet erişim imkânına sahip olduğu, hanelerin \%96,9'unda cep telefonu olduğu görülmektedir. TUIKK'in verilerinde araştırmamız bağlamında dikkat çeken bir diğer önemli istatistik de internet kullanım amaçlarının sorgulandığı verilerdir. İnternet kullanım amaçları dikkate alındığında, 2016 yılının ilk üç ayında internet kullanan bireylerin \%82,4'ü sosyal medya üzerinde profil oluşturma, mesaj gönderme veya fotoğraf vb. içerik paylaşırken, bunu $\% 74,5$ ile paylaşım sitelerinden video izleme, \%69,5 ile online haber, gazete ya da dergi okuma, \%65,9 ile sağlkla ilgili bilgi aramanın takip ettiği görülmektedir (http://tuik.gov.tr). Tüm bu rakamlar bize Türkiye'de yoğun internet kullanımının yapıldığını göstermenin yanında interneti sağlık bilgilerine ulaşma $(\% 65,9)$ amacıyla da kullandığımızı göstermektedir. İnternete erişimimizin artması sağlı alanı için de önemli firsatları beraberinde getirmiştir. Kişisel bilgisayar ve akıllı telefon taleplerinin artmasılyla sağllk personellerinin de hastaların da internet kullanımları artmıştır. Sağlık bilgileri internette en çok aranan, ihtiyaç duyulan konulardan biri haline gelmiştir. İnternet ve beraberinde gelişen sosyal medya, sadece hastalıklarla ilgili genel bilgilerin öğrenildiği yer değil, aynı zamanda sağlıla ilgili tavsiye almak amaçlı da kullanılan bir platform olmuştur (Görkemli, 2017:125). Sağlık alanında internetin aktif olarak kullanılmasının bazı dezavantajları da görülmektedir. Kişilerin internet ortamında birçok hastalı̆̆a ulaşabilmeleri hastalık hastası olmalarına neden olabilmekte, hatalı 
bilgilerle çeşitli yanılgılara sürüklenebilmekte, alternatif durumlar karşısında tedavisini sorgulayabilmektedir. Ayrıca bilgilerin güncel olup olmadığından emin değilken geçmiş bilgilerden yola çıkarak çeşitli sağlık davranışları sergilemekte ve dolayısıyla sağlıklarının kötü etkilenmesine neden olabilmektedirler (Günler Eryiğit, 2015: 36).

Pew Araştırma Merkezi tarafından yürütülen "İnternet ve Amerikan Yaşamı Projesi” ne göre, Amerikalı İnternet kullanıcılarının yaklaşık \% 80'i sağlı bilgilerine erişmek için İnternet'i kullanmaktadır. Bununla birlikte araştırmaya göre internet kullanıcılarının yaklaşık 85 milyonu, İnternet'te bulunan içeriğin kalitesini değerlendirmeden çevrimiçi sağlık tavsiyesi almaktadır. Sağlık bilgileri için internete ne kadar çok kullanıcı erişirse, kaliteye olan ilgi de o kadar artacaktır (Daraz vd., 2019: 1885). Ayrıca "sağlık bilgi kalitesi" konusunda da bir fikir birliğinin sağlanıp, standartların belirlenmesi internetteki sağlık bilgilerinin bu standartlara göre yeniden oluşturulması önem taşımaktadır.

\section{Sağlık İletişimi ile İlgili Yapılmış Çeşitli Çalışmalar}

Literatürde çeşitli hastalıklarla ilgili videoları araştıran çeşitli çalışmalar mevcuttur. Fakat dünyada ciddi bir kriz yaratan, bir anda dikkatleri üzerine çeken ve neredeyse tüm yaşamsal faaliyetlerin aksamasına neden olan bir pandemi ile ilgili üretilmiş videolardaki bilgilerin incelendiği araştırmaya rastlanılmamıştır. Bu araştırma pandemi gibi ciddi ve acil önlemlerin alınması gereken bir durumda, doğru bilgilere ulaşılmada YouTube videolarının etkinliğini kontrol etmeyi amaçlamaktadır.

Sağlık iletişimi ile ilgili yapılmış dikkatimizi çeken ilk çalışma "Assessing the Credibility of the "YouTube Approach" to Health Information on Acute Myocardial Infarction"dur. Çalışmada YouTube'da yer alan sağlık bilgileri içeren videolar incelenmiştir. Akut hakkındaki videoların güvenilirliği analiz edilmiş, doğru bilgi ile video bilgileri kıyaslanmıştır (Pant vd, 2012).

"Identifying Measures Used for Assessing Quality of YouTube Videos with Patient Health Information: A Review of Current Literature" başlıklı çalışmada ise hasta sağlığı bilgisi içeren YouTube videoları incelenmiştir. YouTube'da son yıllarda artan hastaları eğiten videoların içeriklerinin kalitesi değerlendirilmiştir (Gabarron, 2013).

YouTube, Vimeo ve Veoh gibi sosyal video platformlarına yüklenen bilgilerin değerlendirildiği "Misleading Health-Related Information Promoted Through Video-Based Social Media: Anorexia on YouTube" başlıklı çalışmada ise içeriklerin güvenilirliği incelenerek yanıltıcı bilgilerin ayırt edilmesi amaçlanmıştır (Syed Abdul vd, 2013).

"Sağlık İletişiminde Yalan Haber Yanlış Enformasyon Sorunu ve Doğrulama Platformları" başlıklı çalışmada, sağlık alanında yeni medya ortamında yayılan enformasyonların yanlışlığından yola çıkılmış ve bir doğrulama platformu geliştirilmesinin üzerinde durulmuştur. Konu ile ilgili teyit.org doğrulama platformunun sağlık ile ilgili bilgilerdeki incelemeleri ortaya koyulmaya çalış1lmıştır (Ünal \& Taylan, 2017).

"Sağlık İletişiminde Yeni Yaklaşımlar: Dijital Medya Kullanımı" başlıklı çalışmada internet teknolojisinin birey hayatına getirdiği kolaylıkların sağlık alanına da yansıdığını ifade etmektedir. Kullanıcıların içerik ürettiği internet ortamındaki ücretsiz ulaşım kolaylı̆̆ı birçok kişinin bu kaynağa başvurmasını artırdığı ve online sağlık bilgisi aramanın getirdiği kolaylıklar yanında bir de teknoloji okur yazarlığını zorunlu hale getirdiği aktarılmaktadır (Gencer vd, 2019).

Yaylacı ve arkadaşlarının (2015) "Youtube Kaynaklı Türkçe 'Temel Yaşam Desteği' ve 'Kalp Masajı' Videolarının Güvenilirliği”’ çalışmasında, 2010 kardiyopulmoner resüsitasyon (KPR) kılavuzu yayınlandıktan sonra YouTube'a yüklenen Türkçe kalp masajı ve temel yaşam desteği videolarının güvenilirliği araştırılmıştır. Sonuç olarak YouTube videolarının eğitim materyali olarak kullanılıp kullanılmayacağını ifade edilen bir sembolün kullanılması fikri savunulmuştur. 
"Fighting COVID-19 misinformation on social media: Experimental evidence for a scalable accuracy nudge intervention" başlıklı çalışmada, yanlış bilgilerin insanların zorluklarını artırdığı ifade edilmiş, Covid-19 ile ilgili sosyal medya bilgileri incelenmiştir. Çalışmaya göre, 1.600'den fazla katılımcıyla yapılan çalışmada elde edilen veriler insanların yaptıkları paylaşımların doğruluğunu yeterince düşünmediğini göstermektedir (Pennycook vd, 2020).

\section{Covid-19 Hakkında}

Covid-19, Koronavirüs $(\mathrm{CoV})$ ailesi içinden türemiş yeni nesil bir virüstür. Koronavirüsler hayvanlarda ve insanlarda hastalıklara neden olabilen bir virüs türüdür. Orta Doğu Solunum Sendromu (MERS-CoV) olarak bilinen, tek hörgüçlü develerden insana bulaşan ve Şiddetli Akut Solunum Sendromu (SARS-CoV) olarak bilinen misk kedilerinden insana bulaşan hastalıkların da sebebi Koronavirüs ailesidir. Aynı ailenin birçok farklı virüs türünün hayvanlarda mevcut olduğu fakat henüz insanlara bulaşmadığı da bilinmektedir (Sağlık Bakanlığı, 2020: 3). Covid-19 dünyada ilk defa Aralık 2019 tarihinde Çin Halk Cumhuriyeti'nin Vuhan bölgesinde görülmüş ve hastalar üzerinde yapılan incelemeler neticesinde 13 Ocak 2020 tarihinde tanımlanmıştır. Covid-19 salgının başlangıç noktası Vuhan bölgesindeki deniz ürünleri ve hayvan pazarları olarak tespit edilmiştir. Virüs ortaya çıkışından çok kısa bir süre sonra Vuhan şehri ve Hubei eyaleti başta olmak üzere önce Çin Halk Cumhuriyeti'nin diğer eyalet ve şehirlerine, daha sonra da tüm dünyaya yayılmıştır (https://covid19bilgi.saglik.gov.tr/tr/ 2020).

Koronavirüslerin insanlarda rastlanan türleri (HCoV-229E, HCoV-OC43, HCoV-NL63 ve HKU1-CoV) soğuk algınlığına sebep olan virüslerdir (Bayraktar, Altaş vd., 2015: 414). Fakat 2003 yılında SARS-CoV 21. yüzyılın ilk "uluslararası sağlık acil durumu" olarak ortaya çıkmış (Uluslararası Sağlık Tüzüğü, 2015) ve yüzlerce insanın hayatını kaybetmesine neden olmuştur. SARS-Cov'dan yaklaşı 10 yıl sonra yine korona ailesinden ortaya çıkan ve insana bulaşabilen yeni bir virüs tespit edilmiştir (Kurtaran, 2014: 135). MERS-CoV adı verilen bu virüs o tarihe kadar hayvanlarda da rastlanılmamış bir virüstür. İlk defa 2012 yılında Arabistan'da tespit edilmiş olsa da daha sonraki araştırmalar MERS-CoV'un ilk vakasının Nisan 2012'de Ürdün Zarga' da bir hastanede görüldüğ̈nü ortaya çıkarmıştır (Sağlık Bakanlığı, 2020: 3). SARS, MERS ve yeni tür Covid-19 aynı virüs ailesinden gelseler de Covid-19'un diğer iki virüsten bazı farklılıkları vardır. 2003 yılında ortaya çıkan SARS salgını WHO verilerine göre 29 ülkede etkin olmuş ve 774 ölüm gerçekleştirmiştir. MERS ise hâlâ kontrol altına alınamamış ve 27 ülkede toplam 2494 vaka görülmüş ve bu vakaların 858'i ölümle sonuçlanmıştır (Ak, 2020: 27) . Covid-19 ise çok daha kısa sürede çok daha fazla ölüme yol açmıştır. Covid-19'un hızlı ilerleyen bir virüs olması, tespit edilemeyen vaka sayılarının yüksek olma durumunu ortaya çıkarmaktadır. Covid-19'un SARS ve MERS'den daha sorunlu yönü hızlı ilerlemesidir. Özellikle hane içi vaka oranı çok yüksektir (Wu \& McGoogan, 2020: 1239-1241). 10 Mayıs tarihli WHO verilerine göre Çin, İtalya, ABD ve İspanya'nın da olduğu 215 ülkede, 3.925.815 kişiye Covid-19 teşhisi koyulmuştur. Teşhis edilen hastaların 274.488'i ölümle sonuçlanmıştır (www.who.int 2020).

Koronavirüsler şeklinden dolayı Korona (taç) ismini almıştır. Yapılan çalışmalar sonucunda dört türe ayrılarak incelenmektedir. Alfa, Beta, Gama ve Delta şeklinde sinıflandırılan Koronavirüsler insan, yarasa, domuz, kedi, köpek, kemirgen ve kanatlllar gibi hem evcil hem de yabani hayvanlarda bulunabilmektedir. "İnsanlarda Koronavirüsün neden olduğu hastalık spektrumu basit soğuk algınlığından ağır akut solunum sendromuna (Severe Acute Respiratory Syndrome, SARS) kadar değişkenlik gösterebilmektedir. İnsan ve hayvanlarda çeşitli derecelerde respiratuar, enterik, hepatik, nefrotik ve nörolojik tutulumlarla seyreden klinik tablolara neden olabilmektedir" (Sağlık Bakanlığı, 2020: 5-6).

Covid-19 virüsünden etkilenenlerde ortaya çıkan ilk belirtiler yoğun olarak ateş, öksürük ve nefes darlığıdır. Daha şiddetli seyrettiği durumlarda zatürree, ağır solunum yetmezliği, böbrek yetmezliği ve ölüm görülebilmektedir. Buna karşılık bazı insanlarda ise virüsün herhangi bir sağlık 
problemine yol açmadığ 1 da görülmüştür. Virüsler genellikle, taşıyıcıların öksürmesi ve aksırması sonucu yayılan damlacıkların solunması ve ya hastaların solunum parçacıkları ile kirlenmiş yüzeylere dokunanların ellerini yıkamadan ağız, burun ve gözlerine dokunmaları sonucu bulaşmaktadır (covid19bilgi.saglik.gov.tr). Covid-19 henüz yeni tanındığ1 için Covid-19 ile ilgili yapılan çalışmalar da yeni yeni sonuçlanmaktadır. Şu ana kadar yapılan çalışmalar hastalığın inkübasyon süresini 2-14 gün aralığında göstermektedir fakat virüsün dış ortamlardaki dayanıklılık süresi net olarak bilinmemektedir (Sağlık Bakanlığı, 2020: 6).

Covid-19 ile ilgili şuana kadar edinilen bilgilere göre (covid19bilgi.saglik.gov.tr):

- Vakaların yüzde 80'i hastalığı hafif geçirmektedir.

- Vakaların \%20'si hastane koşullarında tedavi edilmektedir.

- Hastalık, genellikle 60 yaş ve üzerindeki kişileri daha fazla etkilemektedir.

Virüsten en çok etkilenen kişiler (covid19bilgi.saglik.gov.tr):

- $\quad 60$ yaş üstü olanlar

- $\quad$ Ciddi kronik tıbbi rahatsızlikları olan insanlar:

- Kalp hastalı̆̆1

- $\quad$ Hipertansiyon

- $\quad$ Diyabet

- $\quad$ Kronik Solunum yolu hastalığ1

- $\quad$ Kanser gibi

- $\quad$ Sağlık çalışanlarıdır.

Yapılan çalışmalarda elde edilen bulgular Covid-19'un çocuklarda yetişkinlere göre daha az etkili olduğu oraya çıkmıştır. Bugüne kadar tespit edilen çocuk vakalar sayıca daha az olmakla birlikte, hastalık seyri de yetişkinlere göre daha hafiftir. Çocuk hastalarda şimdiye kadar ölüm vakası ile karşılaşılmamıştır. Hamilelerde yapılan analizler ise hastalığın seyrinin hamile olmayan insanlar ile aynı olduğunu ama fetüste herhangi bir olumsuz etkiye sebep olmadığını göstermektedir. Ayrıca anneden bebeğe bulaşma durumuna da rastlanılmamıştır (covid19bilgi.saglik.gov.tr).

Hastalıktan korunma yolları ise henüz çok net değildir. Bilinen etkin bir tedavisi şuan yoktur. Hastaların durumlarına göre destek tedavileri uygulanmaktadır. Bazı ilaçlar ile ilgili araştırmalar yapılmaktadır fakat henüz ulaşılabilmiş bir sonuç yoktur. Genel olarak SARS-CoV-2 virüslerinin cansız yüzeylerde bulunabilme durumu olmakla birlikte hastalık oluşturacak miktarda bulunmaması nedeniyle paket veya kargo ile bulaşması beklenmemektedir. Dünya Sağlık Örgütü, CDC (ABD Hastalık Kontrol ve Korunma Merkezi) ve ECDC'nin (Avrupa Hastalık Önleme ve Kontrol Merkezi) de bu konuda herhangi bir kısıtlayıcı tedbiri yoktur. Akut solunum rahatsızlıklarının bulaşma riskini azaltan temel ilkeleri Covid-19 için de geçerlidir. Bunlar (covid19bilgi.saglik.gov.tr);

- $\quad$ En az 20 saniye olmak koşulu ile sabunla eller dikkatlice temizlenmelidir. Su ve sabunun olmadığı durumlarda alkol bazlı el antiseptiği kullanılmalıdır.

- $\quad$ Temizlenmemiş el ile ağız, göz ve buruna dokunulmamalıdır.

- Hasta insanlar ile temas edilmemeli, edilmek durumunda kalınırsa en az 1 metre mesafe korunmalidır. 


\section{• Sağlık merkezlerinde hastaların bulunması nedeniyle mümkün oldukça gitmekten kaçınılmalıdır.}

- $\quad$ Öksürme ve hapşırma durumlarında ağız ve burun tek kullanımlık kâğıt mendiller ile örtülmeli, mendilin bulunmadığı durumlarda dirsek içi kullanılmalıdır.

- Kalabalık yerlerden kaçınılmalı, eğer girmek zorunda kalınıyorsa tıbbi maske kullanılmalıdır.

- $\quad$ Az pişmiş ve çiğ hayvan ürünleri tüketilmemeli, iyi pişmiş yiyecekler tercih edilmelidir.

- Hayvan pazarlarından kaçınılmalıdır.

Sağlık Bakanlığı gibi WHO’da Covid-19 ile ilgili açıklamalar yapmaktadır. WHO bilgilerine göre de sağlıklı bireylerin enfeksiyon taşıyan bireylerle ilgilenmesi durumu dışında maske takmalarına gerek yoktur. Maske takması gereken kişiler, enfeksiyon taşıyan bireylerle ilgilenenler, öksürenler, hapşıranlar şeklinde açıklanmıştır. Ayrıca maskelerin ellerin temizlenmesi ile birlikte bir koruma sağlayacağı, temizliğe önem verilmeden maskenin bir koruma sağlamayacağı da belirtmiş̦tir (www.who.int 2020).

WHO, kamuoyunda tartışma yaratan bazı konulara da açıklık getirmiştir. WHO'nun tartışmalı konular hakkında yaptığı açıklamalar şöyledir (www.who.int 2020);

- Virüsler radyo dalgaları veya mobil ağlar ile dolaşamaz. Covid-19'da 5G yada başka bir ağ ile yayılamaz. yayılmaktadır.

Havanın sıcaklığı virüsü yok etmez. Sıcak havaya sahip ülkelerde de Covid-19

Covid-19'a yakalanıp iyileşebilirsiniz bu durum tekrar yakalanmayacağınız anlamina gelmez.

- $\quad$ Nefesini 10 saniyeden daha fazla tutabilenlerin Covid-19 virüsüne yakalanmadıkları yönündeki ifadeler hatalıdır.

- Covid-19 sadece nemli ve sicak havaya sahip yerlerde yayılmaz, tüm alanlarda bulunabilir. İklim ne olursa olsun Covid-19 riski vardır.

- $\quad$ Soğuk hava ve kar da Covid-19'u öldürmez.

- $\quad$ Sicak banyo Koronavirüsü önlemez. Banyo suyu ne kadar sıcak olursa olsun vücut 1sis1 $36,5^{\circ} \mathrm{C}$ ile $37^{\circ} \mathrm{C}$ arasinda kalır.

- $\quad$ Sivrisinekler 1sırıkları ile Koronavirüs bulaşmaz.

- $\quad$ El kurutma makineleri Koronavirüsü yok etmez.

- V Vücudu alkol ve klor püskürterek temizlemek vücuda girmiş olan virüsleri öldürmez.

- Zatürre aşıları Koronavirüse karşı korumaz.

- $\quad$ Burnu salin ile temizlemek Koronavirüsten koruduğuna dair bir kanıt yoktur.

- $\quad$ Sarımsak yemek Koronavirüsten koruduğuna dair bir kanıt yoktur.

Ayrıca bu açıklamalara ek olarak ifade edebileceğimiz bir açıklama da Sağlık Bakanlığı tarafından yapılmıştır. Bakanlık tuzlu su ile burnu düzenli temizlemenin ve sirke kullanımının Covid19 virüsüne karşı bir koruma sağlamadığını açıklamıştır (covid19bilgi.saglik.gov.tr). 


\section{İncelenen Videolar}

$\mathrm{Bu}$ araştırmada ele alınan videolar içerik analizi yöntemi ile değerlendirilmiştir. Sözel, yazılı ve diğer materyallerin nesnel ve sistemli bir şekilde incelenmesini olanaklı kılan içerik analizi yöntemi (Tavşancıl ve Aslan, 2001) gazete, roman, televizyon programı gibi birçok mecrada kaydedilmiş metinlerin de incelenmesinde kullanılan bir yöntemdir (Neuendorf, 2002:1). İçerik analizi birbirlerine benzeyen verileri çeşitli kategoriler ve sınıflamalarla bir araya getirerek herkes tarafından anlaşılabilir hale getirmektir (Yıldırım ve Şimşek, 2000:162). İçerik analizi kapsamında öncelikle örneklem seçimi yapılmaktadır. Örneklem seçimi ardından kategori ve analiz birimlerinin belirlenmesi aşaması gelmekte, bu aşamadan sonra verilerin toplanması ve kodlaması yapılmaktadır. Dördüncü ve son aşamada ise değerlendirme, çıkarsama ve yorumlama yapılmaktadır (Bilgin, 2014:11). Yapılan bu araştırmada da bahsedilen aşamalar uygulanmıştır. İçerik analizi yöntemine göre oluşturulmuş tablolar sonuç kısmında paylaşılmıştır. Tabloların yorumlanması kısmında anahtar ifadelerin bağlamları da değerlendirilerek yorumlanmıştır. Bağlamların doğru aktarılabilmesi için videoların özet ifadelerine de yer verilmiştir.

$\mathrm{Bu}$ araştırmada çağımızın sağlık bilgilerine ulaşma yöntemlerinden biri olan video izleme sitelerindeki sağlık bilgilerinin yeterli düzeyde sağlık bilgisi içermediği ve ayrıca hatalı bilgiler aktardığ 1 düşüncesinden yola çıkılmıştır. Bu bağlamda konuşmacıların doktor olduğu ve Covid-19 ile ilgili bilgi paylaştıkları YouTube videoları ele alınmıştır. Bahsedilen videoların değerlendirilme kriteri olarak WHO ve Sağlık Bakanlığı'na bağlı kurum ve kuruluşların internet sitelerinde Covid19 ile ilgili aktardıkları bilgiler referans alınmıştır. Bu bilgiler ışığında videolarda;

- $\quad$ Covid-19 ile ilgili genel bilgi paylaşımı yapilıyor mu ve Covid-19'u diğer

Koronavirüslerden daha tehlikeli yapan özelliklerine değiniliyor mu?

- Covid-19'un bulaşma şekilleri ve bulaşmasına mani olacak tedbirler

hakkında bilgi aktarılıyor mu?

- Covid-19'un belirtileri hakkında bilgi veriyor mu?

- $\quad$ WHO ile Sağlık Bakanlığı’’nın açıkladıkları bilgilerin aksi yönde bilgi

paylaşıyorlar mı?

Sorularına cevap aranmıştır. Bu açıdan araştırmada içerik karşılaştırması yapılmıştır. Video söylemlerinin WHO ve Sağlık Bakanlığı söylemleri ile uygunluğu ya da aykırılığı incelenmiş, Covid19 hakkındaki YouTube videolarının doğru bilgiyi aktarma durumu kontrol edilmiştir.

Videolar Nisan 2020 tarihinde "doktor açıklaması Corona", "doktor açıklaması korona", anahtar ifadeleri ile taranmıştır. Covid-19 yeni ortaya çıkan bir virüs olduğu için tarih sınırlandırılması, Covid-19'un dünyada ve Türkiye'de en çok gündeme geldiği Ocak ayı ile çalışmanın videolarının izlendiği 24 Nisan 2020 tarihi aralığında sınırlandırılmıştır. Ayrıca sadece Türkçe yayınlanmış videolar tercih edilmiştir. Videolar görüntüleme sayısına göre sıralanmış, böylece en çok izlenilen videolarla ulaşılmıştır. Televizyon programlarından üretilmiş YouTube videoları elenmiştir. Oluşan sıralamaya göre en çok izlenilen 10 video seçilmiştir. En çok izlenilen videoların tercih edilme sebebi en çok etkileşimi gerçekleştirmiş olmalarıdır. Daha fazla video incelenmemesinin sebebi, diğer videoların popülarite oranlarının seçilenlere göre düşük olmasıdır. Sadece doktorlar tarafından yapılan açılamaların tercih edilmesi ise virüsün etkisinin insanlar tarafından önemsenmesi göz önünde bulundurulduğunda doktor açıklamalarına daha fazla değer verildiğine olan inançtır. 
Tablo 1: İncelenen Videolara Ait Bazı Bilgiler

\begin{tabular}{|c|c|c|c|c|c|c|}
\hline Video & $\begin{array}{c}\text { Yayınlanma } \\
\text { Tarihi }\end{array}$ & $\begin{array}{c}\text { İzlenme } \\
\text { Say1s1 }\end{array}$ & $\begin{array}{c}\text { Beğenilme } \\
\text { Sayıs }\end{array}$ & $\begin{array}{c}\text { Beğenilmeme } \\
\text { Say1s1 }\end{array}$ & $\begin{array}{c}\text { Yorum } \\
\text { Sayıs1 }\end{array}$ & $\begin{array}{c}\text { İncelenme } \\
\text { Tarihi }\end{array}$ \\
\hline 1.Video & 01.02 .2020 & 1.296 .025 & 34.000 & 1.500 & 1.805 & 20.04 .2020 \\
\hline 2.Video & 13.03 .2020 & 1.001 .953 & 11.000 & 1.800 & 2.927 & 20.04 .2020 \\
\hline 3.Video & 25.03 .2020 & 965.090 & 11.000 & 1.000 & 1.784 & 20.04 .2020 \\
\hline 4.Video & 10.02 .2020 & 540.726 & 7.700 & 693 & 942 & 21.04 .2020 \\
\hline 5.Video & 11.03 .2020 & 196.980 & 13.000 & 416 & 1.145 & 22.04 .2020 \\
\hline 6.Video & 23.02 .2020 & 181.372 & 2.500 & 252 & 571 & 23.04 .2020 \\
\hline 7.Video & 24.02 .2020 & 167.395 & 2.900 & 91 & 214 & 23.04 .2020 \\
\hline 8.Video & 23.03 .2020 & 148.146 & 2.800 & 122 & 206 & 23.04 .2020 \\
\hline 9.Video & 12.04 .2020 & 76.935 & 1000 & 120 & 202 & 23.04 .2020 \\
\hline 10.Video & 18.03 .2020 & 36.292 & 371 & 33 & 47 & 24.04 .2020 \\
\hline Toplam & & 4.610 .914 & 86.271 & 6.027 & 9.843 & \\
\hline
\end{tabular}

Videolar ile ilgili ifade edilmesi gereken önemli bir husus videoların bir kısmında geleneksel medyada tanınmış kişilerin (Armağan Çağlayan, Dr. Ender Saraç, Cansu Canan Özgen gibi) varlığının da görülmüş olduğudur. Videoların bazılarının daha popüler hal almasında bu sebebin de etkin olduğuna inanmaktayız. Fakat tüm videolar için böyle bir durum söz konusu değildir. Popüler videoların bazıları ise sadece YouTube sayesinde ün kazanmışlara (Dr. Aydın Gökşin, Dr. Ceylan Kayalı gibi) aittir.

Video 1: Araştırmanın başında açıklanan sınırlılıkta karşımıza çıan ilk video "Flu Tv" isimli YouTube kanalı için çekilmiş “Olmaz Öyle Saçma Tıp” adlı programdır. Programda Dr. Oytun Erbaş Korona ile ilgili açıklamalarda bulunmaktadır. Video 1 Şubat 2020 tarihlidir ve bizim incelediğimiz tarihte (20.04.2020) video 1.296 .025 görüntüleme sayısına sahiptir. Video 34.000 beğeni (like) alırken 1.500 izleyici ise beğenmediğini (dislike) belirtmiştir ve video 8.57 dakikadır. Erbaş, videoya virüslerin genel yapısından bahsederek başlamıştır. Bir virüsün 1/10.000 mutasyona uğrama ihtimali olduğunu ve mutasyona uğramış virüs (Korona) ile insanın teması sonucu Covid-19 virüsünün insana sıçradığını ifade etmiştir. Erbaş videoda, Covid-19 virüsünün soğuk algınlığından farklı olarak zatürree yaptığını ve bu zatürree sürecinin çok ağır seyri olduğunu daha sonraki aşamalarda akciğer yetmezliği ve buna bağlı olarak ölüme yol açabildiğini aktarmıştır. Covid-19'a bağlı ölüm oranın \%3 olduğunu, buna rağmen Korona ailesinin diğer virüsleri olan Mers ve Sars'ın \%20 ölüm oranlarında olduğunu belirterek Covid-19'un daha düşük bir ölüm oranına sahip olduğu bilgisini paylaşmıştır. Korona ile Influenza virüslerinin de kıyaslamasını yapan Erbaş Covid-19'un Influenza gibi olmayacağını çünkü İnfluenza'nın insandan insana geçerken bile mutasyona uğradığını fakat Korona'da bir mutasyon durumunun söz konusu olmadığını da aktarmıştır. Covid-19'un altı aylık bir dönemde yayılacağını ve ortalama 1.000.000 insanı enfekte edeceğini, enfekte insanlardan da yaklaşık 30.000 insanın hayatını kaybetmesine neden olacağını söylemiştir. Erbaş, kronik rahatsızlıklara bağlı olarak oranın değişeceğini ifade ederek kalp, koah, kanser gibi rahatsızlıkları olanlarda ölüm oranın \%40'lara kadar çıkabileceğini aktarmıştır. Bir süre daha dünyayı meşgul edecek olan bu virüsten ötürü paniğe gerek olmadığını, korunmak için ellerin en az 30 saniye dirseklere kadar gün içinde 3-4 defa yıkanması gerektiğini, kalabalık ve virüsün çok olduğu hastane gibi ortamlarda UVC lambalarla virüslerin temizlenebileceğini de aktarmıştır. UVC lambaların insan gözünde yanıklara neden olma ihtimaline karşı insanların olmadığı zamanlarda 1-2 saat çalıştırılması gerektiğini söyleyen Erbaş, ayrıca tuzlu su lavajı ile ağız ve burnun virüslerden temizlenebileceğini de belirtmiştir. Enfekte olmak için ortalama 10.000 ile 100.000 virüse ihtiyaç olduğunu, virüsün yerleşmesi ile vücuda alınması arasında 4-5 saatlik bir zaman olduğunu bu zaman diliminde lavaj yapıldığı takdirde virüslerin vücuda girmesinin önüne geçileceğini de ifade etmiştir. Hasta olmayan insanların maske takmasına gerek olmadığını, virüsten sadece N95 maskelerin koruduğunu geriye kalan maskelerin yanlardan hava aldığı için korumada bir anlam taşımadığını söyleyen Erbaş, 
hastalık belirtisi taşıyan insanların ise maske kullanması gerektiğini söylemiştir. Virüsün ilk Çin'de görülmesini ise Çin'in kalabalık olmasına ve otantik hayvan alışkanlıklarına bağlamıştır. Son olarak Covid-19'un da içinde bulunduğu Koronavirüsleri ile ilgili zarflı yapıda bir virüs olduğunu güneşli ve kuru ortamlarda 3-6 saat arası yaşayabildiğini nemli yerlerde daha dirençli olduğunu eklemiştir.

Video 2: İncelenen ikinci video "Bold Medya" isimli YouTube kanalına aittir. Videoda açıklama yapan doktor Doç. Dr. Yavuz Dizdar'dır. Video 13 Mart 2020 tarihinde yayınlanmış ve videonun incelendiği tarihte (20.04.2020) 1.001 .953 görüntülenme sayısına sahiptir. Video 11.000 beğeni (like) alırken 1.800 beğenmeme (dislike) almıştır ve süre olarak 10:48 dakikadır. Dizdar videoda virüsün daha önce Türkiye'ye geldiğini, bizi enfekte ettiğini fakat bize bir şey yapmadığını belirtmiştir. Turizm Bakanlığı ile Milli Eğitim Bakanlığ 1 kapsamında alınan tedbirlerin olayı yükselttiğini kendisinin kuş gribi ve domuz gribi dönemlerini de yaşadığını, bizim (Türkiye'nin) geçirdiğimiz gribin tanısını koyamadığımızı ve olayların arkasında başka bir senaryo olduğunu ifade etmiştir. Tedbir olarak, el yıkama ve sık sık oda havalandırmayı tavsiye eden Dizdar, 2.5 ve ya 1,5 metre gibi sosyal mesafeye gerek olmadığını ve okulları tatil etmeye de gerek olmadığını (çocuklarda vaka olmadığı için) aktarmıştır. Virüsün ölümcül olma durumunun 80 yaş ve üzeri insanlar için önemli olduğunu, o yaş aralığında virüse maruz kalanlarda \%14 ölüm oranı olduğunu, genel profilde ise virüsün \%2 ölüm oranında olduğunu ifade etmiştir. Maske takma konusuna da değinen Dizdar, maskeyi hastaların takması gerektiğini belirterek sağlıklı insanların maske takmasına gerek olmadığını da belirtmiştir. Tüm virüslerin $26^{\circ} \mathrm{C}$ üzerinde dış ortamlarda yaşayamayacağını da videoda aktarmıştır. Bizim virüsle daha önceden temas ettiğimizi (hastalığı geçirdiğimizi) yeni bir kriz olmadığını ve virüsün mutasyona uğramasının kolay olmadığı için Covid-19'a yakalanıp iyileşenlerin tekrar virüsten etkilenmelerinin mümkün olmadığını ifade etmiştir. Covid-19'un üretilmiş bir virüs olması durumunda aşısının kısa zamanda çıkacağını da aktaran Dizdar, el yıkamanın etkin bir mücadele olduğunu eklemiştir. Ayrıca kıyafetlerde ya da dışarıdan alınmış ürünlerde ütü buharının da virüsleri yok etmek için etkili olacağını aktararak videoyu bitirmiştir.

Video 3: İncelenen üçüncü video da Doç. Dr. Yavuz Dizdar'a aittir. "Üçüncü Bin Y11 Akademi" isimli YouTube kanalında yayınlanmıştır. Video 25 Mart 2020 tarihinde yayınlanmış ve incelendiği gün (20.04.2020) 965.090 görüntülenme sayısına ulaşmıştır. Video 11.000 beğeni (like), 1.000 beğenmeme (dislike) almış ve 3.34 dakikadır. Videoda Yavuz Dizdar Koronavirüs salgının bilinçli olarak üretildiğini ifade etmiştir. İddiasına delil olarak 2015 yılında Menachery, Yount Jr, Debbink, Agnihothram, Gralinski, Plante ve Randell tarafından yayınlanmış "A SARS-like cluster of circulating bat coronaviruses shows potential for human emergence" makalesini göstermiştir. "2015 Aralık ayında yayınlanmış makalede anlaşıldığı gibi, Covid-19 olarak bilinen virüs oluşturulmuş bir virüstür" ifadesi ile önemli bir iddiada bulunmuştur. Yaşanan hezeyan durumunun bilinçli olarak bu noktaya sürüklendiğini ve bu noktaya gelmede WHO'nun etkili olduğunu da belirtmiştir. Dizdar, açıklamasına şöyle devam etmiştir; "Başından beri virüsün önemli olduğunu WHO açılkladı. Bu virüs geçecek, şuan 50 yaş üstüne bilinçli olarak yöneltilmiştir, evinizde kalın. Bir dönem içinde dünyada bir değişiklik meydana gelecek planlanmış senaryo sürüyor. Küresel sermayenin bir hareketi var. Olup olmadığı bile tartışılacak bir virüsün dünyayı böyle bir panik seviyesine çekmesi şaşırtıcıdır."

Video 4: İncelenen dördüncü video da Doç. Dr. Yavuz Dizdar'ın videosudur. Video, "196sekiz" isimli YouTube kanalında yayınlanmıştır. 10 Şubat 2020 tarihinde yayınlanmış olan video incelendiği tarihte (21.04.2020) 540.726 görüntülenme sayısına sahiptir. Video, 7700 beğeni (like) ve 693 beğenmeme (dislike) almıştır ve 18:17 dakikadır. Dizdar videoda bütün dünyanın şuan gereksiz bir panik içinde olduğunu belirtmiştir. Virüsün geçmişine baktığımızda bir aylık bir mazisi olduğunu, hatta daha fazlası olduğunu ifade eden Dizdar, vakaların Korona olup olmadıklarını da bilemediğimizi söylemiştir. Vuhan'daki rakamlar üzerinden bakıldığında bugün (videonun çekildiği gün) ciddi bir sorun yoktur diyen Dizdar, hastalığın bir paniğe dönüşmesini ise çalan ambulans sirenleri, maskeler, acil görüntüleri ile pazarlanmasına bağlamıştır. Maskelerin büyük bir bölümünün 
koruyucu özelliği olmadığını, sadece takanların hasta olması durumunda virüsün dışarı çıkmasını engelleyebileceğini söylemiş ve insanların "maske, tılsım ya da boncukla da eğer inanıyorlarsa" korunabileceklerini eklemiştir. Çin'in virüse karşı müdahalesini de eleştiren Dizdar, Çin'in ilk başta ev ödevini yapmadığını, salgını hafife aldığını daha sonra ise abartılı bir tablo sergilediğini belirtmiş ve konuya çok farklı bir boyut getirerek, birkaç olayın virüs salgını ile paralellik gösterdiğini, WHO'nun panik halinde açıklama yaptığını ve bu açıklamanın Çin'in ekonomik açıdan baskılanması için yapıldığını ifade etmiştir. Virüsün ilerleyen günlerdeki seyri hakkında da değerlendirme yapan Dizdar, bir ay daha böyle bir havanın devam edeceğini, sonra birşey olmadığının anlaşılacağını aktarmıştır. SARS'ın kontrol altına alınamadığı gibi Covid-19 da kontrol altına alınamayacağını fakat bir süre sonra unutulacağını belirten Dizdar,"Bu kadar enfekte olan kişiye birşey olmuyorsa birşey olmayacaktır" diyerek devam etmiştir. Dizdar, genç birisinin virüsü aldığında en fazla hastalanıp yatacağını ama kronik bozukluğu olan birisi için ölümcül seyredeceğini de belirterek, insanların her yıl grip nedeniyle yaşamlarını yitirdiğini bu virüsün de kuş gribi, domuz gribinde olduğu gibi endüstriyel bir adım olduğunu ve aşısının 20 ay gibi bir zamanda çıacağını paylaşmıştır. Aşının çıktıktan sonra satabilmesi için bu hastalığın tekrar 1sıtılacağını ifade eden Dizdar'a göre aşı üretimi için on milyonlarca rakam gerekir. Hastalığın kuluçka döneminin 14 gün olmasının yanlış anlaşıldığını, bir eşya ya da dış ortamda -hele de güneşte- virüsün hayatta kalma süresinin birkaç saatten fazla olamayacağını, virüslerin çoğalabilmesi için başka hücrelere ihtiyaç duyduğunu, sağlam çalışan bir hücreyi ele geçirip kendisi için çalıştırarak hayatta kalabileceklerini söyleyen Dizdar, son olarak eğer belirli bir yaşın üzerinde değilsen, ciğerlerin sağlamsa normal grip olman ile Korona olman arasında bir fark yok diyerek konuşmasını sonlandırmıştır.

Video 5: İncelenen beşinci video "Dr. Aydın" isimli YouTube kanalında yayınlanmış olan Dr. Aydın Gökşin'e ait videodur. Video 11 Mart 2020 tarihinde yayınlanmış ve incelendiği gün (22.04.2020) 196.980 görüntülenme sayısındadır. Video 13.000 beğeni (like) ve 416 beğenmeme (dislike) almış, süre olarak 8:19 dakikadır. Dr. Gökşin, videoyu Türkiye'de vaka açıklanmadan önce kaydettiğini ve eğer vaka olmasaydı videoyu yayınlamayacağını açıklayan bir konuşma ile başlamıştır. Sosyal medya ve basının oluşturacağı panik dolayısı ile vakalar başladıktan sonra içerik üretemeyeceğini kaydeden Gökşin, bu nedenle erken çekim yaptığını açıklamıştır. Gökşin videonun ilk dakikalarında videoyu izleyenleri Halk Sağlığı Genel Müdürlüğü'nün internet sitesi ile WHO'nun internet sitesine yönlendirmiştir. Halk Sağlığı Genel Müdürlügü̈nün sürekli güncel bilgiler paylaştığını ve gerekli önlemlerin aldığını da sürekli tekrarlamıştır. Açıklamalarında kaos ortamından uzaklaşılması gerektiğini, tedbir alınması gerektiğini ifade eden Gökșin, hastalık belirtilerini de izah etmiştir. Gökşin hastalığın ilk belirtileri olarak baş ağrısı, öksürük ve ani ateş sıralamıştır. Bu belirtilerin üst solunum rahatsızlıklarında da görüldügünü, dolayısıyla bu belirtilerin direkt Korona anlamına gelmediğini, fakat bu belirtiler varsa maske ile beraber bir sağlık kuruluşuna başvurması gerektiğini ifade etmiştir. Açıklamalarına devam eden Gökşin, Covid-19'un daha sonraki süreçte solunum yetmezliği ve böbrek yetmezliğine neden olduğunu da eklemiştir. İzleyicilerini uyaran Gökşin, Covid-19'un internette gösterildiği gibi ani ölümlere neden olmadığını, sağlıklı bireylerin kolay kolay bu virüsten ölmediğini belirtmiştir. Virüsü alanların \%10'unda hastalığın ağır seyrettiğini \%3'lük bir ölüm oranına sahip olduğunu, hastalığı ağır geçiren kesimin büyük bir bölümünde farklı rahatsızlıklar olduğunu ve ölenlerin sadece \%19'unun 59 yaş altı olduğunu da açıklamıştır. Gökşin ifadelerini “Gençlerin bu virüsten korunması gerekir çünkü gençler etkilenmese de aile büyüklerine bulaştırma ihtimalleri yüksektir. Ani ölüm gösteren videolar epilepsi krizi geçiren insan görüntüleri ve Korona ile alakası yok. En önemli korunma yöntemi el ylkamak. Ellerin yeteri kadar temizlenmesi lazım. Alkol bazlı el dezenfektanı da el yıkar gibi kullanılmalı. Kalabalık ortamdan uzak durulmall, insanlarla bir metreden fazla mesafe koyun. Doğru beslenme virüsü öldürmez ama bağışıklık sistemini güçlendirir. Maskeye gerek yok. Bir hastalık belirtisi varsa maske takın. Aklınıza takılanları WHO ve Halk Sağlı̆̆ resmi sitesine girerek kontrol edin." cümleleri ile bitirmiştir. 
Video 6: İncelediğimiz altıncı video Oytun Erbaş'a ait "6 dolu" isimli YouTube kanalında 23 Şubat 2020 tarihinde yayınlanmış 3:52 dakikalık videodur. Video 2.500 beğeni (like), 252 beğenmeme (dislike) almış incelendiği gün (23.04.2020) 181.372 izlenme sayısına sahiptir. Erbaş videoda virüsün belirli genetik yapıda olan insanlara atladığını belirtiyor. "Vuhan'da markette balık satana bir şey olmamıştır" diyen Erbaş, düşüncesinin sebebini de balık satıcısının bir süre sonra virüse karşı bağışıklık kazanmasına bağlamıştır. Genel nüfusun 1/3'ünün bu virüsten çok etkileneceğini, 1/3 normal oranda etkileneceğini, 1/3 ise aşırı etkileneceğini ifade eden Erbaş insanların kendilerinin hangi 1/3 gurubunda olduğunu bilemeyeceği için tedbirli olmamı gerektiğini ifade etmiştir. Videoda virüsün Türkiye'ye gelmeyeceğini çünkü bu virüsün belirli genetik yapısı olan insanlara yayıldığını (kısa boylu ve çekik gözlülerde yayıldı) da belirtmiştir. Her virüsün tutunma yerlerinin farklı olduğunu söyleyen Erbaş, ayrıca her insanın yapısının farklı olduğunu bu virüsün kimi insanlara bir şey yapabileceğini kimi insanlara ise bir şey yapamayacağını eklemiştir. Genetik özelliklere tekrar değinen Erbaş AC2 proteinin her insanda aynı oranda olmadığını sarışınlarda, çekik gözlülerde ve kısa boylularda proteinin fazla olduğunu, beyaz tenlilerde orta derecede olduğunu ve siyahlarda ise çok az olduğunu belirterek sarışın çekik gözlü ve kısa boyluların bu virüsü kapma ihtimalinin daha çok olduğunu ifade etmiştir. Dünyada belirli virüs kuşakları olduğunu Vuhan'ın da hem kalabalık hem de virüs kuşağında olduğu için bu virüsün orada çıktığını ve doğal seleksiyonla 1/3'ün öleceğini, 1/3'ün duruma bağl1 olduğunu, 1/3'ün ise hayatta kalacağını ifade ederek videoyu sonlandırmıştır.

Video 7: İnceleyeceğimiz yedinci video ise Dr. Ender Saraç'a aittir. "Dr. Ender Saraç" isimli YouTube kanalında 24 Şubat 2020 tarihinde yayınlanan video 10:55 dakikadır. İncelendiği gün (23.04.2020) 167.395 görüntülenme sayısına sahiptir. Video 2900 beğeni (like), 91 beğenmeme (dislike) almıştır. Saraç, videoya Koronavirüs fobisinin, Koronavirüs paniğinin, Koronavirüsten daha fazla zarar verdiğini belirterek başlıyor. "Nedir Korona? fazla girmeyeceğim" diyen Saraç, Koronavirüsü "çeşitli hayvan türlerinden insana bulaşan bir gribal enfeksiyon" olarak tanımlıyor. Virüsün öksürük, baş ağrısı, bronşit, kas ağrısı, karında şişlik, halsizlik gibi belirtileri olduğunu ve gribal enfeksiyonlara yol açtığını ifade etmiştir. Hatta Covid-19'un daha önce bilinen enfeksiyonlara göre daha az ölümcül olduğunu da eklemiştir. İleri yaşta olmayanların, kortizon, kanser, tüberkilos, şeker ve bağışıklık sistemi gibi ciddi sorunları olmayanların korkmamasını tavsiye etmiştir. Özellikle gençlerde ölümcül olmadığını da açıkça dile getirmiştir. Fakat aktardığı bilgilerin virüsün ciddiye alınmaması gerektiğini göstermediğini ifade eden Saraç "virüsler her sene kendini değiştirir. Bunlar çok akıllı canlılardır. Metrobüslerle, minibüslerle, vapurlarla, otobüslerle birçok yolla süratli bir şekilde yayılabilir." diyerek virüsün bulaşma yollarını izah etmiştir. Ölüm oranına da değinen Saraç, ölüm oranının \%3 olduğunu bu oranın daha düşük olmamasını da yaş ve bağışıklık sistemleri düşük olanlardan kaynaklandığını ifade etmiştir. İyi beslenmeye de videoda vurgu yapmıştır. Protein almanın önemini aktarmış, balık ve süt ürünlerinin protein kaynağı olduğunu ayrıca bitkisel proteinlere de ihtiyaç olduğunu eklemiştir. D vitaminin tamamlanmasını tavsiye eden Saraç, güneş ışığının alınmadığı dönemlerde $\mathrm{D}$ vitaminin düştüğünü bu nedenle solaiumların tercih edilebileceğini ayrıca çinkoya da dikkat edilmesi gerektiğini belirtmiştir. Kabuklu tüm gıdalarda çinkonun bulunduğunu da söyleyen Saraç, C4 vitaminin de önemli olduğunu limon, portakal, sivri biber, çiğ yenilen yeşilliklerde $\mathrm{C}$ vitamini olduğunu ve bunların da tüketilmesi gerektiğini aktarmıştır. Demir oranlarına da değinen Saraç; pekmez, kuru incir, kuru kayısı, mor meyvelerin demiri güçlendirdiğini söyledikten sonra, virüsü yok etmek için antiviral maddelerin varlı̆̆ından bahsetmiştir. Karanfil, kekik, zahter, sarımsak, soğan, pırasa, defneyaprağının virüsleri durdurucu, yavaşlatıcı etkisi olduğunu, bu gıdaların tüketilmesinin Korona'nın da yavaşlamasına katkı sağlayacağını ifade etmiştir. Saraç bolca gida önerdiği videonun sonunda "ozon terapi” (majör) yönteminin önemine değinmiş ve ozon terapinin kendileri tarafindan virüs tedavilerinde yıllardır uygulandığını ve olumlu sonuçlar aldıklarını aktarmıştır. Saraç videoda bir çay da tavsiye etmiş, çayın hazırlanışını "bir kupa çayı iyice kaynatın kaynatırken içine 2-3 parmak ucu zencefil atın. Kaynadıktan sonra altını kapatın 1 tutam ekinezya, 1 tutam ebegümeci çiçeği, 1 tutam mürver, 2 karanfil sonra süzün ve ince bir dilim 
limon biraz da ıhlamur atın. 5 dakika demleyin" şeklinde aktarmış ve şekersiz tüketilmesini de vurgulamıştır. Ayrıca kullanılan basit maskelere bir iki damla karanfil veya defne yağı sürerek virüslerin etkisiz hale getirilebileceğinden de bahsederek videoyu bitirmiştir.

Video 8: İnceleyeceğimiz sekizinci video "Turisto" isimli YouTube kanalının yayınladığı videodur. Video 23 Mart 2020 tarihinde yayınlanmış ve incelenen gün (23.04.2020) 148.146 görüntülenme sayısına sahiptir. Video 2.800 beğeni (like) ve 122 beğenmeme (dislike) almıştır. Görüntüde araçta giden bir adamın konuşması mevcuttur. Videonun başlığına "Bu doktora kulak verin" ifadesi olduğu için incelenme kapsamına alınmıştır. Video 4:15 dakikadır. Doktor açıklamasında "virüs de bir canlı yașamak istiyor, yaşamak için öldürüyor. Bizim yaşamak için öldürdüğ̈̈müz canlılar gibi o da öldürüyor. Belki de hayatta kalmak için mutasyona uğrayacak. Yapılacak şeyleri biliyorsunuz elleri yıkamal, sosyal mesafeye dikkat edilmeli gibi... Bu virüsün kuluçka dönemi 14 gün ortalama 5-6 günde çıkar ama en uzun 14 gün olduğu için 14 gün diye söyleniyor. Belki de geçirip bağış̧ıllık kazandınız bu ancak testle anlaşılabilir. Her pozitif testli hasta olacak diye bir şey yok. 60 yaşının üzerinde kalp ve akciğer hastalı̆̆ olanları tutarak akciğerlerini berbat edip solunum cihazına bağlanması gerekiyor, bu hastaları kaybediyoruz. Sağllk personeli de $\% 30$ ile \%80 arasında bu hastalı̆̆a tutulacak. Să̆llk personellerini kötülemeyin. 14 gün sonra bu personeller evlerine gidecek size cildiyeciler, dermatologlar, kadın doğumcular bakacak enfeksiyoncular çekilecek. Birlik ve beraberlik içinde hareket etmeliyiz. Bu hastalığı yeneceğiz ama kaç fire ile. Devlet sokağa çıkmayın diyorsa çıkmayın, panik olmayın." ifadelerini kullanmıştır.

Video 9: İnceleyeceğimiz dokuzuncu video Dr. Ceylan Kayalı'ya aittir. Video "Turisto" isimli YouTube kanalında 12.04.2020 tarihinde yayınlanmıştır. İncelendiği gün (23.04.2020) 76.935 görüntülenme sayısına ulaşmıştır. Video 1.000 beğeni (like), 120 beğenmeme (dislike) almıştır ve 4:53 dakikadır. Videoda Dr. Kayalı Türk ilacını keşfettiğini söylemiştir. İlacın içeriğinde bor, sodyum bikarbonat ve suyun olduğunu aktarmıştır. (Bir bardak suya yarım kaşık bor, yarım kaşı sodyum bikarbonat koyup karıştırıyor, sonra içiyor.) Bu karışımın Koronavirüsün zehri olduğunu iddia etmiştir. İnsanları zehirlemediğinden fakat virüsleri, mikropları öldürdüğünden bahsetmiş. Kola, meyve suyu, etil alkolle de karıştırılabileceğini ayrıca damardan da verilebileceğini söylemiştir. Kullanımda bir farklı yöntemden daha bahseden Kayalı, diboron denilen hava şeklinde olan bir bileşiği olduğunu, içine eter koymak suretiyle, komadaki hastalara verilirse akciğeri parçalayan virüslerin de yok edilebileceğini aktarmıştır. Komadaki hastalarımıza hemen uygulama teklifini de yaparak videoyu sonlandırmıştır.

Video 10: İnceleyeceğimiz son video Doç. Dr. Aytuğ Altundağ’a aittir. Video "Cansu Canan Özgen" isimli YouTube kanalında 18 Mart 2020 tarihinde yayınlanmıștır. Videonun analiz edildiği gün (24.04.2020) tarihinde 36.292 izlenme sayısına sahiptir. Video 24:52 dakikadır, incelendiği gün toplam 371 (beğeni) like, 33 (beğenmeme) dislike almıştır. Diğer programlardan farklı bir yayın formatında olan bu video bir programcı ve bir konuk konuşması şeklinde ilerliyor. (Oytun Erbaş ve Yavuz Dizdar'ın da videolarında soru soran bir programcı var fakat görüntüde başka kimse olmadığı için aktarılmamıştır.) $\mathrm{Bu}$ video bir Tv programı formatı ile hazırlanmıştır. Koronavirüs nasıl yayılıyor? sorusu ile başlıyor Altundağ' 1 cevabı; "bilim kurulunun açılamalarını mutlaka takip edelim. Korona'yı birbirimizi bilinçlendirdikçe, önemimizi aldıkça durdurabiliriz. Illk adım bilinçlenmek. Damlacık yolu ile yayıliyor. Üst solunum yolu enfeksiyonu gibi başliyor daha sonra akciğere iniyor. Zaten en büyük sorun AC2 enzime yapışı zatürree ve solunum yetmezliğine yol açıyor." şeklinde olmuştur. Altundağ'ın virüsün yayılmasına karşı alınması gereken önlemler ile ilgili ilk tavsiyesi sosyal mesafeyi korumalıyız olmuştur. Maskenin de önemine değinen Altundağ, maskenin hastalığın yayılmaması için önemli olduğunu, hastaların damlacık yaymaması için maske kullanması gerektiğini ifade etmiștir. "Kimse hastalanmış olmak istemez. Hastalanmış bireyi damgalamamalıyı. Sosyal mesafe ve kişisel temizlik önemlidir. Hijyenik el yıkama yapmalıyız ellerimizi en az 20 saniye yıkamalıyı. Dezenfektan veya \%80 alkol içeren kolonya da kullanmalıyzz. Gençlerden bağışıklık sistemi sorunlu olanlar var. 40 yaş altı ölüm oranı çok düşük fakat hiç gençler, 
çocuklar hastalanmıyor düşüncesi yanlış, bu gurupta ölüm oranı \%0.2'dir. 80 yaş üzeri ölüm oranı \%15'tir, arada 30 kat fark var" cümleleri ile virüsün öneminde dikkat çekmiştir. Virüsün ölümcüllüğünü etkileyen bazı nüansların varlığından da bahseden Altundağ, sigara içenlerde bu hastalığa yakalanma ve ağır seyretme ihtimalinin çok yüksek olduğunu ifade etmiştir. Korona'da solunum yetmezliğinin sigara içenlerde 14 kat daha fazla olduğunun ortaya çıktığını da eklemiştir. Hastalıktaki tek risk faktörünün yaşlı olmak olmadığını, hipertansiyon, solunum kanser gibi rahatsızlıkların da etkileri artırdığını aktarmıştır. "Bana birşey olmaz" rehaveti olmaması gerektiğini vurgulayan Altundağ, "panik olmayın İtalya'da tek vaka ile başladı daha sonra logaritmik bir artış oldu. Büyük aile ortamında genç yaşl iç içe bu nedenle yaşlı bireylere bulaşma ihtimali çok yüksek. Bağışıklık sistemimizi güçlü tutmalıyız. Kuluçka süresi 2-3-14 günde olabilir. Net bir bulgu yok." ifadeleri ile tedbirin gerekçelerini izah etmiştir. Korona'da en önemli bulgunun \%80 oranında ateş ve yorgunluk hissi olduğunu, boğaz ağnısı, kuru öksürük nefes darlığının da sık görüldüğünü hatta seyrek de olsa burun tıkanıklığı ve ishalin bile görülebildiğini aktarmıştır. Rakamların artmasıyla bazı kriterlerin değişebileceğini belirten Altundağ, bu değişikliklerin davranış değişikliklerine de yola açacağını belirtmiştir. Panik olmamanın önemini vurgulayan doktor, Çin ve İtalya kıyaslaması yaparak Çin'in mücadelesindeki başarısından bahsetmiş̧ir. İtalya'da günde 2000 yeni vaka varken Çin'de 20 olmasının, Çin ve Japonya'nın hastalıkla iyi mücadele edildiğini göstermektedir diyen Altundağ aşının da geleceğini ifade etmiştir. Fakat aşı tarihi ile ilgili bir bilgi paylaşamamış, ne zaman geleceğinin bilinmediğini ifade etmiştir. Bağışıklık sistemi ile ilgili özel bir tavsiye vermekten ziyade vücut direncini korumayı tavsiye etmiş, D,C vitaminleri ile balık yağının öneminden bahsetmiştir. Sigara içilmemesini özellikle vurgulamış ve ağzı nemli tutmayı tavsiye ederek videodaki sözlerini sonlandırmıştır.

\section{Bulgular ve Değerlendirme}

Araştırma kapsamında videolar analiz edilirken araştırmanın başında aktarılan temel sorulardan yola çıkılmıştır. Covid-19 virüsü, Korona ailesinden olmakla birlikte aynı ailenin diğer virüslerinden farklı bir yapıya sahiptir. Videoların analizinde ilk odaklandığımız nokta videolarda Covid-19 ile ilgili genel bilgilerin aktarılması ve Covid-19'un diğer Koronavirüslerden farklılığın vurgulanma durumudur. 
Tablo 2: Covid-19 ile ilgili genel bilgi paylaşımı yapılıyor mu ve Covid-19'u diğer Koronavirüslerden daha tehlikeli yapan özelliklerine değiniliyor mu?

\begin{tabular}{|c|c|c|c|c|c|c|c|c|c|c|c|}
\hline Video & V. 1 & V. 2 & V. 3 & V. 4 & V. 5 & V. 6 & V. 7 & V. 8 & V. 9 & V. 10 & Top \\
\hline Sars & 3 & & & 4 & 2 & & & & & 4 & 13 \\
\hline Mers & 1 & & & 1 & & & & & & & 2 \\
\hline Akciğer & 1 & & & 2 & & & & 1 & & 3 & 7 \\
\hline Zatürre & 2 & & & & & & & & & 1 & 3 \\
\hline $\begin{array}{c}\text { Solunum } \\
\text { Yetmezliği }\end{array}$ & & & & & 1 & & & & & 4 & 5 \\
\hline AC2 & 2 & & & & & 1 & & & & 3 & 6 \\
\hline $\begin{array}{c}\text { Ölüm Oranı } \\
\text { Kuluçka Süresi }\end{array}$ & 5 & 3 & & & 3 & & 2 & & & 6 & 19 \\
\hline Mutasyon & 6 & 2 & & & & & & 2 & & 1 & 11 \\
\hline Enfekte & 2 & 2 & & 4 & & & & & & & 8 \\
\hline $\begin{array}{c}\text { Çin } \\
\text { Nem Durumu }\end{array}$ & 2 & 1 & 1 & 5 & & 3 & & & & 6 & 17 \\
\hline $\begin{array}{c}\text { Kuş / Domuz } \\
\text { Gribi }\end{array}$ & & 2 & & 6 & & & & & & 1 & 9 \\
\hline Zarflı Yapısı & 2 & & & & & & & & & & 2 \\
\hline $\begin{array}{c}\text { Kronik } \\
\text { Rahatsızlık }\end{array}$ & 1 & & & 2 & 1 & & 1 & 1 & & 1 & 7 \\
\hline Sağlık Bakanlığ 1 & & & & & 4 & & & & & 2 & 6 \\
\hline $\begin{array}{c}\text { Who } \\
\text { Toplam }\end{array}$ & 29 & 10 & 2 & 27 & 14 & 6 & 3 & 5 & & 37 & 133 \\
\hline
\end{tabular}

Tabloyu incelediğimizde videoların büyük bir bölümünde değinilen anahtar ifadenin "Kronik Rahatsızlık" olduğu görülmektedir. On videonun altısında Covid-19'un kronik rahatsızlık ile olan ilişkisi aktarılmıştır. Videoların \%50'sinde yani 5'inde ise "ölüm oranı" ve "Çin" ifadeleri yer almıştır. Covid-19 ile kıyaslama yapılmada aktarılan Sars, Mers, Domuz Gribi ve Kuş Gribi gibi farklı hastalıklar da videolarda değinilmiştir. 19 defa tekrarlanarak en sık tekrarlanan kavramın ölüm oranı olduğu görülmüştür. Tabloda sıralanan ifadeleri en fazla barındıran video 10 numaralı video olmuştur. Covid-19 ile ilgili genel bilgiler ve Covid-19'u diğer Koronavirüslerinden ayıran özellikler video 9'da hiç aktarılmamıştır. Video 3 ve 7 de ise sınırlı olarak değinilmiştir. Hastalığın kuluçka süresine sadece üç video değinmiştir. Virüsün özelliği olan zarflı yapısı sadece 1. videoda aktarılmıştır. Solunum yetmezliği ve zatürreye yol açtığı bilgisi de sınırlı sayıda videoda aktarılmıştır. Fakat Sağlık Bakanlığı'na bağlı kurum ve kuruluşların açıklamalarında Covid-19'un genel özellikleri ve Korona ailesinin diğer virüsleri ile arasındaki benzerlikleri ve farklılıkları daha genişçe izah edilmektedir. Korona virüsler ve Covid-19 hakkında Sağlık Bakanlığı'na bağlı internet sitesi, "Yeni Korona virüs Hastalığ (COVID-19), ilk olarak Çin'in Vuhan Eyaleti'nde Aralık ayının sonlarında solunum yolu belirtileri (ateş, öksürük, nefes darliğı) gelişen bir grup hastada yapılan araştırmalar sonucunda 13 Ocak 2020'de tanımlanan bir virüstür. Salgın başlangıçta bu bölgedeki deniz ürünleri ve hayvan pazarında bulunanlarda tespit edilmiştir. Daha sonra insandan insana bulaşarak Vuhan başta olmak üzere Hubei eyaletindeki diğer şehirlere ve Çin Halk Cumhuriyeti'nin diğer eyaletlerine ve diğer dünya ülkelerine yayllmıştır. Korona virüsler, hayvanlarda veya insanlarda hastalığa neden olabilecek büyük bir virüs ailesidir. Insanlarda, birkaç korona virüsün soğuk algınlı̆̆ından Orta Doğu Solunum Sendromu (MERS) ve Şiddetli Akut Solunum Sendromu (SARS) gibi daha şiddetli hastalıklara kadar solunum yolu enfeksiyonlarına neden olduğu bilinmektedir. Yeni Korona virüs Hastalığına SAR-CoV-2 virüsü neden olur" açıklamasını yapmıştır 
(https://covid19bilgi.saglik.gov.tr 2020). Ayrıca Sağlık Bakanlığı tarafından hazırlanmış Covid-19 rehberinde ise, "Corona virusler (CoV), soğuk alginlığından Orta Doğu Solunum Sendromu (MERSCoV) ve Şiddetli Akut Solunum Sendromu (SARS-CoV) gibi daha ciddi hastaliklara kadar çeşitli hastalıklara neden olan büyük bir virüs ailesidir. Corona virusler zoonotik olup, hayvanlardan bulaşarak insanlarda hastalık yapabilir. Detayl araştırmalar sonucunda, SARS-CoV'un misk kedilerinden, MERS-CoV'un ise tek hörgüçlü develerden insanlara bulaştı̆̆ ortaya çıkmıştır. Henüz insanlara bulaşmamış olan ancak hayvanlarda saptanan birçok corono virüs mevcuttur. Corona virusların insanlarda dolaşımda olan alt tipleri (HCoV-229E, HCoV-OC43, HCoV-NL63 ve HKU1CoV) çoğunlukla soğuk algınlı̆̆ına sebep olan virüslerdir. SARS-CoV, 21. yüzyılın ilk uluslararası sağlık acil durumu olarak 2003 yllında, daha önceden bilinmeyen bir virüs halinde ortaya çımış olup yüzlerce insanın hayatın kaybetmesine neden olmuştur. Yaklaşık 10 yll sonra Corona virus ailesinden, daha önce insan ya da hayvanlarda varlığı gösterilmemiş olan MERS-CoV (Middle East Respiratory Syndrome Coronavirus) Eylül 2012'de ilk defa insanlarda Suudi Arabistan'da tanımlanmış; ancak daha sonra aslında ilk vakaların Nisan 2012'de Ürdün Zarqa'daki bir hastanede görüldü̈̆̈̈ ortaya çıkmıştır. SARS Corona virus'u ile uzaktan bağlantılı olmasına rağmen, yaşanmış olan SARS tecrübesinden ötürü endişe oluşturmuştur." Bilgileri yer almaktadır (https://hsgm.saglik.gov.tr 2020). Bu benzerlik ve farklilikların izah edilmesi insanlarda oluşturulacak algının güçlenmesi açısından önemlidir. Virüsün basit bir gribal enfeksiyondan çok daha fazlasına neden olduğunu, ölüm yüzdesi düşük görünse bile enfekte olan insan sayısı çok fazla olacağ 1 için virüsten kaynaklı ölümlerin rakamsal olarak yüksek olacağını ifade etmek videoyu izleyen insanların daha tedbirli olmasını sağlayacaktır. Fakat üç video dışındaki diğer videolarda Covid-19'un özellikleri ve diğer Koronavirüslerinden fark1 aktarılmamıştır. Bu durum videoları izleyenlerin Covid-19 virüsü ile ilgili genel bilgilerden ve korona ailesindeki diğer virüslerden ayıran farklardan habersiz olmalarına neden olacaktır.

Tablo 3: Covid-19'un bulaşma şekilleri ve bulaşmasına mani olacak tedbirler hakkında bilgi aktariliyor mu?

\begin{tabular}{|c|c|c|c|c|c|c|c|c|c|c|c|}
\hline Video & V. 1 & V.2 & V. 3 & V. 4 & V. 5 & V. 6 & V.7 & V. 8 & V.9 & V.10 & Top \\
\hline El Y1kama & 3 & 1 & & & 3 & & & 1 & & 2 & 10 \\
\hline Havalandırma & & 2 & & & & & & & & & 2 \\
\hline Dezenfektan & & 2 & & 2 & 2 & & & & & 1 & 7 \\
\hline Maske & 5 & 2 & & 7 & 6 & & 3 & & & 3 & 25 \\
\hline Sosyal Mesafe & & 1 & & & 1 & & & 1 & & 7 & 10 \\
\hline Dokunma & & & & & & & & & & 2 & 2 \\
\hline Karantina & & & & 3 & & & & & & & 3 \\
\hline Canlı Hayvan & 6 & 2 & & 5 & & 1 & 1 & & & & 15 \\
\hline Tükürük/Damlacık & & & & 1 & & 1 & & & & 2 & 4 \\
\hline Soluma/Solunum & & & & & & & & & & 2 & 2 \\
\hline Toplam & 14 & 9 & & 18 & 12 & 2 & 4 & 2 & & 19 & 80 \\
\hline
\end{tabular}

Tablo incelendiğinde en çok ifade edilen tedbirin maske olduğu görülmektedir. Sırasıyla 10. video 4. video ve 1 . video en fazla kavramı barındıran videolar olmuştur. 3. ve 9. videoda ise hiçbir kavram yer almamıştır.

Virüsten korunabilmek için virüsün nasıl yayıldığını bilmek oldukça önemlidir. Araştırmada Covid-19'un bulaşma (kişiden kişiye geçişi) ihtimalini azaltma yollarının yani, virüse karşı alınacak tedbirlerin YouTube'daki videolarda aktarılıp aktarılmadığına da dikkat edilmiştir. Virüsün yayılmasını önlemek için alınması gereken tedbirler kapsamında 1. video ellerin yıkanmasına ayrıntılı değinmiştir. El yıkama bilgisi Sağlık Bakanlığı'nın bilgileri ile uyumlu bir şekilde izah 
edilmiştir. Video 2'de el yıkama hakkında bilgi aktarmış ayrıca odaların havalandırılmasının önemine ve dezenfektan kullanımına da değinmiştir. 3 numaralı videolarda bu konu ile ilgili bir bilgiye rastlanılmamış, 5. video yine el yıkamanın önemine değinmiştir. Bu video ayrıca alkol bazlı dezenfektan kullanmanın da önemini aktarmış ve 1-3-4-6-7-9 numaralı videolarda değinilmeyen sosyal mesafeye kuralına da değinmiştir. İnsanlar arası bir metrelik mesafeye dikkat edilmesi konusunda uyaran video bağışıklık sistemini korumak için doğru beslenmeye de vurgu yapmıştır. 7 . video ise virüsün kalabalıkta hızlı yayıldığı ifade etmiştir. 8 numaralı video el yıkamanın ve sosyal mesafe kuralının önemine dikkat çekmiştir. Son olarak 10. video virüsün damlacık yolu ile yayıldığını akciğere indiğini ve sonra zatürreeye dönüştüğünü aktararak bu konuya detaylı bir giriş yapmış ve tedbir olarak da sosyal mesafe, el yıkama, alkol içeren dezenfektan kullanmanın önemini aktarmıştır. Ayrıca videoların neredeyse tamamında maskeye değinilmiştir. Maske ile ilgili bilgi aktaran videoların tamamında maskeyi hasta olmayanların takmasına gerek olmadığı, fakat hastaların takmasının önemli olduğu aktarılmıştır. Aktarılan bilgiler WHO ve Sağlık Bakanlığı'nın paylaştığı bilgiler ile kıyaslandığında bilgilerin doğruluğu ile ilgili bir sorunun olmadığı görülmüştür. Fakat bilgilerin eksikliği de gözlemlenmiş̧ir. Sağlık Bakanlığı el yıkama, alkol bazlı dezenfektan kullanma, sosyal mesafeye uyma tedbirlerinin dişında, temizlenmemiş el ile ağız, göz ve buruna dokunmamayı, hasta insanlar ile temastan kaçınmayı, öksürme, hapşırma gibi durumlarda tek kullanımlık kâğıt mendilleri tercih etmeyi, az pişmiş yiyeceklerden kaçınmayı ve canlı hayvanların satışlarının gerçekleştiği pazarlardan uzak durulmayı da tavsiye etmiştir. Videolarda canlı hayvanlar ile ilgili ifadeler yer almış fakat bu ifadeler korunmak için aktarılan ifadelerden ziyade hastalığın başlangıcını aktarmak için kurulan cümlelerde geçmiştir.

WHO virüsün bulaşma şeklini;

"Hastalık öncelikle kişiden kişiye, COVID-19 olan bir kişi öksürdüğünde, hapşırdiğğnda veya konuştuğunda atılan kü̧̧ük damlacıklar yoluyla yayılır. Bu damlacıklar nispeten ağırdır, çok fazla seyahat etmez ve hızlı bir şekilde yere düşer. İnsanlar nefes alırken bu damlactklart solursa COVID$19^{\prime} a$ yakalanabilirler. Bu yüzden insanlardan en az 1 metre uzakta kalmak önemlidir. Bu damlacıklar, masa, kapı tokmağl ve korkuluk gibi kişinin etrafindaki nesnelere ve yüzeylere inebilir. İnsanlar bu nesnelere veya yüzeylere, ardından gözlerine, burnuna veya ağzına dokunarak enfekte olabilirler." (https://www.who.int 2020) şeklinde izah etmiştir.

Sağl1k Bakanlığı Covid-19 rehberinde ise;

"Hastalığın başlangıcındaki ilk kaynak Huanan Deniz Ürünleri Toptan Satış Pazarında yasadışı olarak satılan vahşi hayvanlar düşünülmekle birlikte, insandan insana ve sağllk merkezlerinde bulaş bildirilmiştir. Şuana kadar hastalığın bulaşma yolunun damlacık yoluyla olduğu bildirilmiştir.” (https://hsgm.saglik.gov.tr 2020) bilgileri aktarılmıştır.

Ayrıca Sağlık Bakanlığı'nın internet sitesinde de konuyla ilgili;

"Hasta bireylerin öksürmeleri aksırmaları ile ortama saçılan damlacıkların solunması ile bulaşır. Hastaların solunum parçacıları ile kirlenmiş yüzeylere dokunulduktan sonra ellerin yıkanmadan yüz, göz, burun veya ağıza götürülmesi ile de virüs alınabilir. Kirli ellerle göz, burun veya ağıza temas etmek risklidir." Bilgileri paylaşılmıştır (https://covid19bilgi.saglik.gov.tr 2020). 
Tablo 4: Covid-19'un belirtileri hakkında bilgi veriyor mu?

\begin{tabular}{|c|c|c|c|c|c|c|c|c|c|c|c|}
\hline Video & V. 1 & V. 2 & V. 3 & V. 4 & V. 5 & V. 6 & V. 7 & V. 8 & V. 9 & V.10 & Top \\
\hline Baş Ağrısı & & & & & 1 & & & & & & 1 \\
\hline Öksürük & 2 & & & 1 & 1 & 1 & 1 & & & 1 & 7 \\
\hline Ateş & & & & & 1 & & 1 & & & 9 & 11 \\
\hline Kas Ağrısı & & & & & & & 1 & & & & 1 \\
\hline Karın Şişliği & & & & & & & 1 & & & & 1 \\
\hline Halsizlik/Yorgunluk & & & & & & & 1 & & & 3 & 4 \\
\hline $\begin{array}{l}\text { Nefes Darlığ̀1/ Göğüs } \\
\text { Ağrıs1 }\end{array}$ & & & & & & & & & & 3 & 3 \\
\hline İshal & & & & & & & & & & 1 & 1 \\
\hline Burun T1kanıklığ1 & 1 & & & & & & & & & 2 & 3 \\
\hline Boğaz ağrısı & 1 & & & & & & & & & 2 & 3 \\
\hline Toplam & 4 & & & 1 & 3 & 1 & 5 & & & 21 & 35 \\
\hline
\end{tabular}

Tablo incelendiğinde en fazla tekrarlanan belirti ates olmuștur. Sirasıyla 10, 7 ve 1 numaralı videolar en fazla belirtileri aktaran videolar olmuştur. 2, 3, 8, ve 9 numaralı videolar ise hiçbir belirtiyi aktarmamıştır.

Virüsün bulaştığı bir kişinin Covid-19'un kendisinde olduğunu anlayabilmesi için çeşitli belirtilerinden haberdar olması da oldukça önemlidir. Bu nedenle videolarda Covid-19'un belirtilerinin aktarılıp aktarılmadığı da incelenmiştir. Virüsün belirtileri ile ilgili kapsamlı bilgi aktaran ilk video 5 numaralı video olmuştur. Virüsün belirtileri olarak baş ağrısı, öksürük, ani ateş sıralanmıştır. Bu belirtilerin üst solunum rahatsızlıklarında da görüldüğü bilgisi de paylaşılarak, videoda bu belirtilerin görüldüğü kişilerin maske takarak hastaneye başvurulması tavsiye edilmiştir. Belirtilere kapsamlı değinen ikinci video ise 7 numaralı video olmuştur. Videoda belirtiler öksürük, baş ağrısı, bronşit, kas ağrısı, karında şişlik, halsizlik olarak sıralanmıştır. Son olarak 10. videoda belirtileri izah etmiştir. 10. video da ateş, yorgunluk hissi, boğaz ağrısı, kuru öksürük, nefes darlığını sık belirtiler olarak aktarmış; seyrek olarak burun tıkanıklığı ve ishalin de görüldüğünü ifade etmiştir.

Hastalığın belirtileri ile ilgii WHO resmi internet sitesinde şöyle açıklamalarda bulunmuştur;

COVID-19'un en yaygın semptomlarl ateş, kuru öksürük ve yorgunluktur. Daha az yaygın

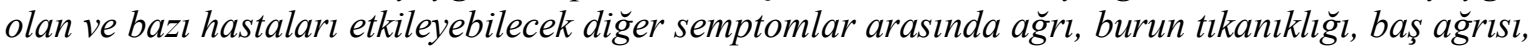
konjonktivit, boğaz ăgrisl, ishal, tat veya koku kaybı veya ciltte kizarıklık veya parmaklarda veya ayak parmaklarında renk değişikliği bulunur. Bu semptomlar genellikle hafiftir ve yavaş yavaş başlar. Bazı insanlar enfekte olur, ancak sadece çok hafif semptomları vardır. Çoğu insan (yaklaşık\% 80) hastane tedavisine ihtiyaç duymadan hastalıktan iyileşir. COVID-19 alan her 5 kişiden yaklaşık l'i ağır hastalanmakta ve nefes almakta güçlük çekmektedir. Yaşlı insanlar ve yüksek tansiyon, kalp ve akciğer sorunlart, diyabet veya kanser gibi altta yatan tıbbi sorunları olanlar ciddi hastalık geliştirme riski altındadır. Bununla birlikte, herkes COVID-19'a yakalayabilir ve ciddi şekilde hastalanabilir. Nefes alma / nefes darlı̆̆ı, göğ̈̈s ağrısı / basıncı veya konuşma veya hareket kaybı ile ilişsili ateş ve / veya öksürük yaşayan her yaştan insan derhal tıbbi yardım almalıdır. Mümkünse, hastanın sağllk kliniğe yönlendirilebilmesi için önce sağllk uzmanını veya tesisi aramanı önerilir" (https://www.who.int 2020)

Sağlık Bakanlığı hazırladığı Covid-19 rehberinde ise;

"Enfeksiyonun yaygın belirtileri solunum semptomları, ateş, öksürük ve dispnedir. Daha ciddi vakalarda, pnömoni, ăgır akut solunum yolu enfeksiyonu, böbrek yetmezliği ve hatta ölüm gelişebilir. Ancak eldeki veriler doğrultusunda hastalı̆̆ı şiddeti konusunda yorum yapılamamaktadır." İfadeleri ile belirtileri izah etmiştir (https://hsgm.saglik.gov.tr 2020). 
Tablo 5: WHO ile Sağlık Bakanlı̆̆g'nın açıkladıkları bilgilerin aksi yönde bilgi paylaşıyorlar mı?

\begin{tabular}{|c|c|c|c|c|c|c|c|c|c|c|c|}
\hline Video & V. 1 & V. 2 & V. 3 & V. 4 & V. 5 & V. 6 & V.7 & V. 8 & V. 9 & V.10 & Top \\
\hline Tuzlu Su Lavaj1 & 3 & & & & & & & & & 1 & 4 \\
\hline Genetik & & & & & & 6 & 1 & & & 2 & 9 \\
\hline Vitamin & & 2 & & & 2 & & 7 & & & 4 & 15 \\
\hline Ozon Terapi & & & & & & & 7 & & & & 7 \\
\hline Bor & & & & & & & & & 5 & & 5 \\
\hline Aș1 & & 5 & & 10 & & & & & & 1 & 16 \\
\hline UVC & 1 & & & & & & & & & & 1 \\
\hline Sarımsak & & & & & 2 & & 1 & & & & 3 \\
\hline Sicak Hava & 1 & 2 & & 1 & & & & & & & 4 \\
\hline Toplam & 5 & 9 & & 11 & 4 & 6 & 16 & & 5 & 8 & 64 \\
\hline
\end{tabular}

Tablo incelendiğinde aşı ve vitamin ifadelerinin sık anıldığı görülmektedir. Video 7 ve video 4 en fazla kavram aktaran videolar olmuştur. 2 ve 8 numaralı videolar ise tabloda yer alan hiçbir kavramı ifade etmemiştir.

Covid-19 ile ilgili en büyük sorunlardan birisi çok fazla hatalı bilginin dolaşımda olmasıdır. Hatalı bilgilerin fazlalığ 1 virüs hakkında bilgi almak isteyen bireylerin doğru bilgiye ulaşılması önünde büyük bir engel oluşturmaktadır. WHO ve Sağlık Bakanlığı'na bağlı kurum ve kuruluşlar Covid-19 ile ilgili bilgileri sürekli aktararak insanların doğru bilgiye ulaşmasını amaçlamıştır. Araştırma kapsamında videolar WHO ve Sağlık Bakanlığı'na bağlı kurum ve kuruluşların açıklamaları ile çelişen bilgiler açısından da ele alınmıştır. İlk çelişen bilgiye 1. Videoda rastlanılmıştır. Videoda, tuzlu su lavajı ile ağız ve burnun virüsten temizleneceği ifade edilmiştir, fakat Sağlık Bakanlığı (covid19bilgi.saglik.gov.tr adresinde) yaptığı açıklamada tuzlu su ile burnu düzenli temizlemenin Covid-19'a karşı bir koruma sağlamadığını açıklamıştır. Ayrıca video 1 de bahsedilen UVC ile virüslerin yok edilebileceği bilgisi WHO ve ya Sağlık Bakanlığı'nın bilgilerinde yer almadığı görülmüştür. Sıcak havada virüslerin yaşayamayacağı bilgisi ise Sağlık Bakanlığı ve WHO ile çelişen bir bilgi olarak tespit edilmiştir. Dikkatimizi çeken ve çelişki taşıyan bir diğer bilgi ise 2. videodadır. Videoda Covid-19 virüsünün daha önce Türkiye'ye geldiği, bir şey yapmadığı ifade edilmiș ve alınan tedbirlerin abartılı olduğu aktarılmıștır. 2 numaralı video 11 Mart 2020 tarihinde yayınlanmıştır ve Türkiye'de ilk resmi vaka da 11 Mart 2020 tarihinde açıklanmıştır (https://tr.euronews.com 2020). Yani videonun yayınlandığg tarihte virüs Türkiye'ye girmiş ve insanları enfekte etmeye başlamıştır. Bu duruma rağmen 2. videoda böyle bir beyanın olması oldukça dikkat çekicidir. 2 numaralı videoda dikkat çeken bir diğer nokta ise aşı vurgusudur. Resmi kurumlar aşı ile ilgili çalışmaların başladığını fakat henüz bulunamadığını ifade etseler de videoda aşı ile ilgili farklı beyanlar yer almıştır. 4. videoda ise genç bireylerin kronik rahatsızlıkları olmadığı taktirde bu virüsten etkilenmeyecekleri, normal bir grip gibi geçirecekleri aktarılmıştır. Fakat gençlerin taşıyıcı olma ihtimaline karşı virüsten korunmaları gerektiği ifade edilmemiştir. Hastalığın seyri boyunca virüsten etkilenmeyenlerin virüsün taşıyıcısı olabildikleri sıklıkla görülmüştür. Bu bilgiye rağmen 4 numaralı videoda geçen bilgi gençler üzerinde fazla rahatlatıcı bir etkiye sahiptir. Aynı konu 5 numaralı videoda da belirtilmiş ama gençlerin taşıyıcı olma ihtimaline karşı tedbirli olmaları gerektiği vurgulanmıştır. Bu açıdan değerlendirildiğinde 4 numaralı video virüsün yayılmasına sebep olabilecek ifadeler barındırmaktadır. 6. Video ise virüsün Türkiye'ye gelmeyeceği çünkü belirli genetik yapıdaki insanlar arasında virüsün yayıldığı iddia edilmiştir. Virüsün Türkiye'ye gelip birçok ölüme sebep olduğu günümüzde bilinen bir gerçektir. Dolayısıyla bu iddia geçersizdir. Ayrıca 6. video 23 Şubat 2020 tarihinde yayınlanmıştır. Fakat 30 Ocak 2020 tarihi itibari ile ABD başta olmak üzere bazı ülkeler virüs nedeni ile Çin'e uçak seferlerini iptal etmiştir (www.milliyet.com.tr 2020).Videonun yayınlandığı gün yani 23 Şubat tarihinde Filipinler'de Çin dışında ilk ölüm haberi de medyada yer almıştır (www.bbc.com 2020). Tüm bu veriler virüsün bir genetik özelliğe göre 
ilerlemediğinin ispatıdır. Aynı videoda $1 / 3$ oranında insanın çok etkileneceği, 1/3 insanın ise hiç etkilenmeyeceği ifade edilmiştir. Böyle bir oran, WHO veya Sağlık Bakanlığı bilgilerinde mevcut değildir. Bu bilgiyi aktaran doktor, bilginin kaynağı hakkında bir bilgi de paylaşmamıştır. 7. videoda ise çeşitli gıda maddeleri ile korunmanın yolu izah edilmiştir. Fakat WHO ve Sağlık Bakanlığı yaptığı açıklamalarda gida maddelerinin doğrudan koruyuculuğu ile ilgili bir bilginin olmadığı açıklanmıştır. Aynı videoda ozon terapi yöntemlerinden de bahsedilmiştir. Fakat bu yöntemin de virüsten koruduğuna dair resmi hiçbir açıklama yoktur. 9. Video Türk ilacı diye ifade edilen bir ilaçtan bahsetmiştir. İlacın içeriğinde su, bor ve sodyum bikarbonat olduğunu aktarmıştır. Oysa WHO burnu salin (sodyum bikarbonat içerir) ile temizlemenin Covid-19'dan korunmada faydalı olduğuna dair bir kanıt olmadığını açıklamıştır. Dolayısıyla bu iddia da WHO açıklamaları ile çelişen bir noktadadır. Özetlemek gerekirse Tablo 5'de yer alan kavramlar Sağlık Bakanlığ 1 ve WHO tarafından hatalı bilgi olarak kabul edilen (ya da hiç değinilmeyen) kavramlardır. 10 numaralı videoda çelişen ifadelerin çok sık kullanıldı ğ görülmektedir fakat 10. videoda ifade edilen kavramlar bağlamları ile değerlendirildiğinde Sağlk Bakanlığı ve WHO ile çelişen bir bilginin olmadığı görülmüştür.

Tüm bu ifadelerin sonunda ortaya çıkan hakikat; incelenen videolarda Covid-19 ile ilgili çok az bilgi paylaşıldığıdır. Covid-19 hakkında bilgi almak isteyenler birkaç video izledikten sonra bile Covid-19 ile ilgili tam bir bilgi edinmiş olmayacaktır. Çünkü aktarılan bilgiler eksiktir. Covid-19 gibi hızlı önlem alınması gerekli olan bir durumda doktorların konuşmacı olduğu videoların bilgi düzeyinin daha yoğun olması ve kulaktan dolma bilgilerden ziyade daha bilimsel verilere dayalı bilgiler olması gerekmektedir. Kayg1 ve korkunun hâkim olduğu bir dönemde tartışma yaratacak söylemlerden ziyade, toplumu bilgilendirecek, kaygı ve korku havasının dağılmasını sağlayacak, doğru yönlendirecek bilgilerin paylaşıldığı videoların olması virüs ile mücadelede daha fazla katk1 yapacağı açıktır. Videolar kapsamlı bilgi aktaramadıkları gibi, kapsamlı bilgiye nasıl ulaşılacağını da aktarmamıştır. Daha kapsamlı bilgiye ulaşmak isteyenleri WHO ve Sağlık Bakanlığı'na bağlı adreslere yönlendiren sadece 5. ve 10. videolar olmuştur. Böyle bir ortamda en iyi bilgiyi tüm bilgilerin toplandığı merkezlerden elde etmenin daha sağlıklı sonuçlar vereceğini göz önünde bulundurmak da oldukça önemlidir.

2005 yılında kurulan YouTube insanların video paylaşımına, görüntülemesine olanak tanıyan ücretsiz bir paylaşım sitesidir. YouTube günümüzde milyonlarca üyesi olan, çok yüksek sayıda izlenme ve video üretme rakamlarına ulaşan bir platformdur. Böyle bir platformun çeşitli sağlık videolarını yayma gücü de göz ardı edilemez. Günümüzde YouTube'un en çok kullanım amacı eğlence olsa da sağlık bilgilerine ulaşmada kullanımı da önemli oranlardadır ve hızla artacağı yapılan çalışmalarda ön görülmektedir (Gabarron vd., 2013: 2). Çağımızda bilginin her aşaması internet aracılığı ile gerçekleşmektedir. Öyleki artık eğitim sistemleri bile internet tabanlı sistemlere entegre olmakta ve her alanın vazgeçilmez öğesi olarak internet her geçen gün daha da güçlenmektedir (Henkoğlu vd., 2017: 146). İnternet ortamında bilgiye erişimin kolay olması insanların bilgi erişimi yönteminde internet tercihini güçlendirirken beraberinde birtakım sıkıntılarında oluşmasına yol açmaktadır. Ücretsiz bir platform olan YouTube'da içerik üretmenin kolaylığı, üretilen içeriklerdeki düzensiz bilgilerin varlığ doğru bilgiye ulaşmanın önünde bir engel oluşturabilmektedir. Sağlık konusunda bilgi aktaran videolar; kişisel deneyimlerden yola çıkan "ev yapımı" videolar olabildiği gibi, çeşitli konularda uzman kişilerin görüşlerinin aktarıldığ 1 videolara kadar geniş bir yelpazeye sahiptir. Videoları izleyip bilgi sahibi olmak isteyenler videoların kimin tarafindan üretildiğinden, ne zaman güncellendiğinden, içeriğgindeki bilgilerin ne kadarının doğru olduğundan habersizdir (Pant vd., 2012: 281-282). Bu durumlar YouTube'daki bilgilerin güvenilirliği sorununu ortaya çıkarmaktadır. Güven problemi Covid-19 virüsü ile ilgili videolar için de geçerlidir.

İncelenen videolar başlığı altında verilen tabloda açıç̧a görüldüğü üzere videoların büyük bir bölümü Şubat ve Mart aylarında oluşturulmuş, sadece bir video Nisan ayında oluşturulmuştur. Videolar ortalama iki aylık bir süre içinde toplamda 4.610.914 görüntüleme sayısına ulaşmıştır. Bu 
rakam bize Korona ile ilgili bilgi almak isteyen insanların interneti ne kadar çok kullandığını gösteren açık bir delildir. Videoyu izleyenlerin sadece \%1,87'si videoyu beğendiğini gösteren "Beğen" ikonuna tıklamış ve sadece $\% 0,21$ 'i videoya yorum yapmıştır. İzlenme oranlarının yüksek olmasına rağmen yorum ve beğeni oranlarının düşük olması videoların içerik olarak izleyenleri tatmin etmediği şeklinde yorumlanabilir.

Eğlence amaçlı oluşturulan video paylaşım uygulaması YouTube, sağlıkla alakalı birçok videoya da ev sahipliği yapmaktadır. Yüksek popülaritesi ve erişim kolaylığı ile birlikte düşünüldügünde videoların insanlar üzerindeki etkileri daha rahat anlaşllacaktır. Böylesine etkin bir platformun düşük kaliteli sağlık bilgileri içermesi, bilgilere erişen insanların dezenformasyona uğramasına neden olmaktadır. Sağlık ile ilgili hele de Covid-19 gibi hızlı yayılan ve dünyada büyük bir soruna neden olan, sokağa çıkma yasağı, okul tatili, seyahat engeli gibi ciddi yaptırımlarla yayılmasının önüne geçilmeye çalışılan bir salgınla ilgili videoların daha düzenli ve net bilgiler içermesi gerektirmektedir. Bu platformdan öğrenilecek yanlış bir bilgilinin birçok insanın hayatını olumsuz etkileyeceğine hatta istenilmeyen ölümlerin oluşmasına bile yol açabileceği gerçeği göz önünde bulundurulmalıdır.

Belirli yasal ve ahlaki sınırları olmakla beraber YouTube özgür bir platformdur. Fakat özgürlük denetimsizlik ya da kontrolsüzlük anlamına gelmemelidir. Özellikle sağlıkla ilgili bilgilerin paylaşımında belirli sınırlamaların olması, içerik üretebilmek için belirli yeterliliklerin olması beklenebilir. Buradaki denetim ve kontrolden kasıt sansür değildir. Sansür gibi baskıcı bir yöntemin YouTube gibi özgürlükçü bir ortamda uygulanması kabul edilemez olmakla birlikte, büyük kitleleri etkileyen özellikle sağlık alanındaki videoların belirli kalitelerde üretilebilmesi için çeşitli çözüm yolları bulunması da gerekmektedir. "İnsanlar istediklerini seçsin, istediklerini izlesin, istediklerine inansın" düşüncesi sağlık alanında özellikle de Covid-19 gibi çok büyük kitleleri tehdit eden salgınlarda bir lüks olarak değerlendirilebilir. Salgın ile mücadelede sokağa çıkmamız, tatile gitmemiz, kafe, restoran ve benzeri yerlerde oturmamız, kalabalık ortamlarda bulunmamı hem bireysel hem de kamu yararına sinırlandırılabiliyorsa YouTube videoları da sinırlandırılabilir olmalıdır. Binark (2007) da yeni ve denetimi zor olan enformasyon ortamının birçok sorunla beraber denetim sorunu getirdiğini aktarmıştır (Avşar, 2017:126). Özellikle terör konulu sosyal medya çalışmalarında sıklıkla değinilen denetim ve güvenlik sorunları sağlık konulu sosyal medya içerikleri için de geçerlidir.

\section{Kaynakça}

Ak, Ö., (2020) Soğuk Algınlığından Ölümcül Salgına! Küresel Kabus. Bilim ve Teknik Dergisi, Mart, 13-27.

Alptekin, Ü. M. (2019). Organ Bağışıyla İlgili YouTube Videolarının Analizi, , (Yayımlanmamış Yüksek Lisans Tezi) Marmara Üniversitesi, Sağlık Bilimleri Enstitüsü.

Altunay, A. (2015). "Bir Sosyalleşme Aracı Olarak Yeni Medya”, Selçuk İletişim Dergisi. Cilt 9 , Say1 1, 410-428.

Avşar, Z. (2017). İnternet Çağında Medya, Terör ve Güvenlik. TRT akademi, 2(3), 116-132.

Aydoğan, F. \& Kırık, A. M. (2012). Alternatif medya olarak yeni medya. Akdeniz Üniversitesi İletişim Fakültesi Dergisi, 18, 58-69.

Aydoğdu, A. G. (2018). Türkiye'de YouTube Yayıncılığı ve YouTuber Olmak. İletişim Kuram ve Araştırma Dergisi, (47). 141-166 
Bayrakdar, F., Altaş, A. B., Korukluoğlu, G. \& Topal, S. (2015). Türkiye'de Tespit Edilen İlk MERS Olgusunun Moleküler Tanıs1 ve Fi Logenetik Analizi. Molecular diagnosis and phylogenetic analysis of the fi rst MERS case in Turkey. Mikrobiyol Bul, 49(3), 414-22.

Bilgin, N. (2014). Sosyal Bilimlerde İçerik Analizi Teknikler ve Örnek Çalışmalar, 3. Basım, Siyasal Kitabevi.

Çalık, D. \& Çınar, Ö. P. (2009). Geçmişten Günümüze Bilgi Yaklaşımları Bilgi Toplumu ve İnternet. XIV. Türkiye'de Internet Konferansi, 12-13.

Daraz, L., Morrow, A. S., Ponce, O. J., Beuschel, B., Farah, M. H., Katabi, A., \& Ding, J. F. (2019). Can Patients Trust Online Health Information? A Meta-Narrative Systematic Review Addressing the Quality of Health Information on the Internet. Journal of general internal medicine, 1884-1891

Gabarron, E., Fernandez-Luque, L., Armayones, M., \& Lau, A. Y. (2013). Identifying Measures Used for Assessing Quality of YouTube Videos With Patient Health Information: a Review of Current Literature. Interactive Journal of Medical Research, 2(1), e6.

Gencer, Z. T., Daşlı, Y. \& Biçer, E. B. (2019). Sağlık İletişiminde Yeni Yaklaşımlar: Dijital Medya Kullanımı. Selçuk Üniversitesi Sosyal Bilimler Meslek Yüksekokulu Dergisi, 22(1), 42-52.

Görkemli, N. (2016). Sağlik İletişiminde İnternet Kullanımı Üzerine Bir Araştırma, The Turkish Online Journal of Design, Art and Communication - TOJDAC January 2017 Volume 7 Issue $1,122-138$.

Güner Yiğit, O. (2015), Bilgi Toplumunda İnternetin Önemi ve Sağlı Üzerindeki Etkileri, KMÜ Sosyal ve Ekonomik Araştırmalar Dergisi 17 (29), 33-40.

Hansen, C., Interrante, J. D., Ailes, E. C., Frey, M. T., Broussard, C. S., Godoshian, V. J., Lewis, C., Polen K., Garcia, A.P. \& Gilboa,S. M. (2016). Assessment of YouTube Videos as a Source of Information on Medication Use in Pregnancy. Pharmacoepidemiology and drug safety, 25(1), 35-44.

Henkoğlu, H. Ş., Keser, H., \& Mahiroğlu, A. (2017) Ortaokul Öğrencilerinin İnternette Bilgi Arama Stratejileri Ölçeği: Bir Ölçek Geliştirme Çalışması. Milli Eğitim Dergisi, 46(215), 145-166.

Işı1k, M. (2018). "Yeni Medyanın, Yeni Yıldızları Youtuberların Türkiye'deki Genel Görünümü” "The 1st International Cultural Informatics, Communication \& Media Studies" Sempozyumu Bildiri Kitab1, 384-393

Kırık, A. M. (2017). Yeni medya aracılığıyla değişen iletişim süreci: Sosyal paylaşım ağlarında gençlerin konumu. Gümüşhane Üniversitesi İletişim Fakültesi Elektronik Dergisi, 5(1), 230261.

Kurtaran, B. (2014). MeRS-Co Virüs ve Diğer Ciddi Seyirli Viral Pnömoniler. ANKEM Derg, 28, 134-140.

Kurulgan, M. \& Argan, M. (2007). Anadolu Üniversitesi Öğrencilerinin İnternet Üzerinden Bilgi Arama Davranışları. Atatürk Üniversitesi Sosyal Bilimler Enstitüsü Dergisi, 9(1), 291-304.

Maigret, E. (2012), Medya ve İletişim Sosyolojisi, (Çev. Halime Yücel), İletişim Yayınları.

Neuendorf, K. A. (2002). The Content Analysis Guidebook, Thousand Oaks, Sage Publications.

Öztürk, Ş. (2015). Sosyal medyada etik sorunlar. Selçuk İletişim Dergisi. Cilt 9, Sayı 1, 287-311. 
Pant, S., Deshmukh, A., Murugiah, K., Kumar, G., Sachdeva, R., ve Mehta, J. L. (2012). Assessing the Credibility of the "YouTube Approach" to Health Information on Acute Myocardial Infarction. Clinical cardiology, 35(5), 281-285.

Paré, G., Malek, J. N., Sicotte, C., ve Lemire, M. (2009). Internet as a Source of Health Information and its Perceived Influence on Personal Empowerment. International Journal of Healthcare Information Systems and Informatics (IJHISI), 4(4), 1-18.

Pennycook, G., McPhetres, J., Zhang, Y., Lu, J. G., \& Rand, D. G. (2020). Fighting COVID-19 Misinformation on Social Media: Experimental Evidence for a Scalable Accuracy-Nudge Intervention. Psychological science, 0956797620939054.

Sağlık Bakanlığı (2020) Covid-19(2019-n CoV Hastalığı) Rehberi (Bilim Kurulu Çalışması), T.C. Sağlık Bakanlığı, https://covid19bilgi.saglik.gov.tr/depo/rehberler/COVID-19_Rehberi.pdf

Syed-Abdul, S., Fernandez-Luque, L., Jian, W. S., Li, Y. C., Crain, S., Hsu, M. H. \& Liou, D. M. (2013). Misleading health-related information promoted through video-based social media: anorexia on YouTube. Journal of medical Internet research, 15(2), e30.

Taşdelen, Ö. Ü. B. (2019) Okul Öncesi Çocuklar için Sağlık İçerikli Eğitici Videoların YouTube Aracılığıyla Kullanılması. Yeni Medyada Çocuk ve İletişim (Edt. Kırık, A.M.) Çizgi Kitapevi, 97-114.

Tavşancıl, E. \& Aslan E. (2001). Sözel, Yazılı ve Diğer Materyaller İçin: İçerik Analizi ve Uygulama Örnekleri, Epsilon Yayınları.

Tosyalı, H. \& Sütçü, C. S. (2016). Sağlık İletişiminde Sosyal Medya Kullanımının Bireyler Üzerindeki Etkileri. Maltepe Üniversitesi İletişim Fakültesi Dergisi, cilt.3, 3-22,

Uluslararas1 Sağlık Tüzüğü, (2015). hssgm.gov.tr/content/documents/uluslararasi_antlas malar/Uluslararas1\%20Sağl1k\%20Tüzüğü.pdf.

Ünal, R. \& Taylan, A. (2017). Sağlık İletişiminde Yalan Haber-Yanlış Enformasyon Sorunu ve Doğrulama Platformları. Atatürk İletişim Dergisi, (14), 81-100.

Wu, Z. \& McGoogan, J. M. (2020). Characteristics of and Important Lessons from the Coronavirus Disease 2019 (COVID-19) outbreak in China: summary of a report of 72314 cases from the Chinese Center for Disease Control and Prevention. Jama 323(13), 1239-1242

Yaylac1, S., Serinken, M., Elicabuk, H., Yılmaz, A., Dal, O. \& Kaya, G. F. (2015). YouTube Kaynakl1 Türkçe "Temel Yaşam Desteği'" ve "Kalp Masaj1" Videolarının Güvenilirliği. Gaziosmanpaşa Üniversitesi Tıp Fakültesi Dergisi, 7(1), 38-45.

Yıldırım, A. \& Şimşek, H. (2006). Sosyal Bilimlerde Nitel Araştırma Yöntemleri. Seçkin Yayıncılık.

Yurdigül, Y. \& Zinderen, İ. E. (2012). Yeni medyada haber dili (Ayşe Paşalı olayı üzerinden geleneksel medya ve internet haberciliği karşlaştırması). The Turkish Online Journal of Design, Art and Communication - TOJDAC July 2012 Volume 2 Issue 3, 81-91.

\section{İnternet Kaynakları:}

http://tuik.gov.tr/PreHaberBultenleri.do?id=21779 Erişim Tarihi: 29.04.2020

https://covid19bilgi.saglik.gov.tr/tr/covid-19-yeni-koronavirus-hastaligi-nedir Erişim Tarihi 12-052020

https://hsgm.saglik.gov.tr/depo/haberler/ncov/2019-nCov_Hastal_Salk_alanlar_Rehberi.pdf Erişim Tarihi: $12-05-2020$

https://www.bbc.com/turkce/haberler-dunya-51347052 Erişim Tarihi: 25.04.2020 
https://www.brandingturkiye.com/YouTube-istatistikleri-guncel/ Erişim Tarihi: 25.04.2020

https://www.medipol.com.tr/bilgi-kosesi/bunlari-biliyor-musunuz/pandemi-nedir-corona-virusuneden-pandemi-ilan-edildi Erişim Tarihi 30.04.2020

https://www.milliyet.com.tr/dunya/son-dakika-corona-virus-nasil-yayildi-6172136 Erişim Tarihi: 30.04 .2020

https://www.who.int/emergencies/diseases/novel-coronavirus-2019 Erişim Tarihi 10.05.2020

https://www.who.int/emergencies/diseases/novel-coronavirus-2019/question-and-answers-hub/q-adetail/q-a-coronaviruses, Erişim Tarihi: 12-05-2020

https://datareportal.com/reports/digital-2019-global-digitaloverview\#: :text=There\%20are\%204.39\%20billion\%20internet,9\%20percent)\%20versus $\%$ 20January $\% 202018 . \&$ text $=3.26 \% 20$ billion $\% 20$ people $\% 20$ use $\% 20$ social,of $\% 20$ more $\% 20$ than\%2010\%20percent Erişim Tarihi: 25.07.2020

https://tr.euronews.com/2020/03/10/sagl-k-bakan-koca-koronavirus-covid-19-salg-n-ile-ilgili-acklama-yap-yor Erişim Tarihi: 30.04.2020

https://covid19bilgi.saglik.gov.tr/tr/ Erişim Tarihi: 20.04.2020

www.who.int Erişim Tarihi: 20.04.2020

www.internetworldstats.com Erişim Tarihi: 28.04.2020

\section{İncelenen Videoların Kaynakları:}

Video 1 https://www.YouTube.com/watch?v=blwj6FIkNnU\&t=1s Erişim Tarihi: 20.04.2020

Video 2 https://www.YouTube.com/watch?v=QDwKUqaFZHU\&t=37s Erişim Tarihi: 20.04.2020

Video 3 https://www.YouTube.com/watch?v=JdyvwCXp4dI\&t=2s Erişim Tarihi: 20.04.2020

Video 4 https://www.YouTube.com/watch?v=luM2vg8g0Hc\&t=48s Erişim Tarihi: 21.04.2020

Video 5 https://www.YouTube.com/watch?v=qbQ8O61GFZo\&t=2s Erişim Tarihi: 22.04.2020

Video 6 https://www.YouTube.com/watch?v=VfY7-irnABs Erişim Tarihi: 23.04.2020

Video 7 https://www.YouTube.com/watch?v=Q2s_sokAHTI Erișim Tarihi: 23.04.2020

Video 8 https://www.YouTube.com/watch?v=cASa1FHVnms\&t=82s Erişim Tarihi: 23.04.2020

Video 9 https://www.YouTube.com/watch?v=Pio4ViIE8Rc\&t=228s Erişim Tarihi: 23.04.2020

Video 10 https://www.YouTube.com/watch?v=VIHkRhvBF4o Erişim Tarihi: 24.04.2020 